\title{
Versatile mechanisms of 2-substituted benzimidazoles in targeted cancer therapy
}

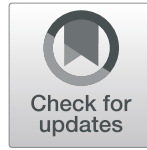

\author{
Heba A. Ibrahim* and Hanan M. Refaat
}

\begin{abstract}
Background: The aim of this review is to provide an overview on diverse anticancer activities of 2-substituted benzimidazole derivatives.

Main body: This review provides a correlation between the various mechanisms of action of benzimidazoles as anticancer and the substitution pattern around the nucleus.

Conclusion: The linker group and substitution at N-1, C-2, C-5, and C-6 positions have been found to be the most contributory factors for anticancer activity. This will help in the further design to afford more selective, potent, and multi-target anticancer of 2-substituted benzimidazole-based compounds.
\end{abstract}

Keywords: Heterocyclic, Benizimidazole, Anticancer, Cytotoxic effect

\section{Background}

Cancer, the uncontrolled, rapid, and pathological proliferations of abnormal cells, is one of the most formidable afflictions in the world jeopardizing human life and health [1-3]. It is the second most life-threatening disease after the cardiovascular disorder according to statistics from the American Cancer Society (ACS) [4, 5]. Cancer can occur in any living cell at any stage of life; the morbidity and mortality associated with disease is on rise. Millions of people worldwide are suffering from this dreaded disease which not only affects the health of the patient but also puts significant socioeconomic, mental, and physical burden on the family members [6-8].

Heterocyclic compounds occupy a central position in medicinal chemistry and are of particular interest and significant importance in the search for new bioactive molecules in the pharmaceutical industry [9]. More interest in the area of benzimidazole-based chemistry was developed in the 1950s, when 5,6-dimethyl-1-( $\alpha$-Dribofuranosyl) benzimidazole was found as an integral part of the structure of vitamin $B_{12}$ [10]. Benzimidazole being an isostere of purine-based nucleic acid found to

\footnotetext{
* Correspondence: hebatalla.ahmed@fue.edu.eg

Department of Pharmaceutical Chemistry, Faculty of Pharmaceutical Sciences and Pharmaceutical Industries, Future University in Egypt, Cairo 11835, Egypt
}

be a privileged lead nucleus widely used in the design of many biologically active molecules [11]. Benzimidazoles exhibit a wide range of biological activities including antibacterial [12], antifungal [13], analgesic [14], and cardiovascular [15] in addition to anticancer activities [16-18].

\section{Main text \\ Chemistry of benzimidazoles}

Benzimidazole is one of the oldest known nitrogen heterocycles and was first synthesized by Hoebrecker [19] then later by Ladenburg [20]. Benzimidazole ring contains two nitrogen atoms with amphoteric nature, possessing both acidic and basic characteristics (Fig. 1). It exists in two equivalent tautomeric forms, in which the hydrogen atom can be located on either of the two nitrogen atoms $[16,18]$.

\section{Synthesis of 2-substituted benzimidazoles}

The synthetic strategy adopted for the preparation of benzimidazoles relies on building up the imidazole ring on a suitable substituted benzene core.

The first benzimidazole was prepared by Hoebrecker [19]. who obtained 2,5-dimethylbenzimidazole by the 


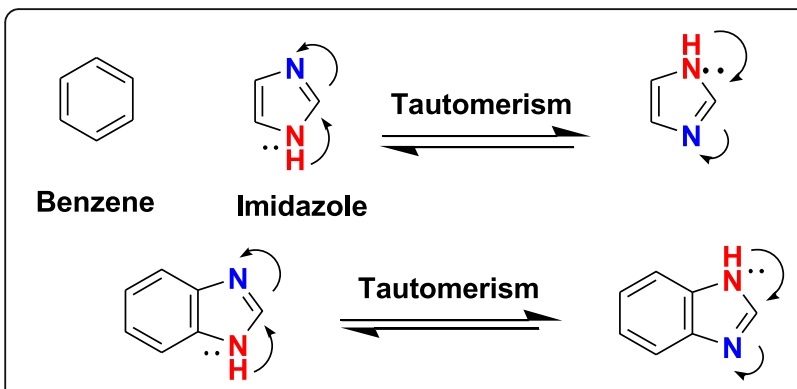

Benzimidazole

Fig. 1 Tautomers of benzimidazole

reduction and dehydration of 2-nitro-4-methylacetanilide (Scheme 1) [21, 22].

In the majority of cases, $o$-phenylenediamines or suitably substituted derivative was used as the starting compound where it was reacted with different one carbon delivering reagents to give the benzimidazole derivatives (Scheme 2). The following reactions were classified according to the reagent used through different pathways from A to R [21-24].

\section{Anticancer activity of 2-substituted benzimidazoles}

Recently, the major side effect associated with the traditional anticancer agents is cytotoxicity towards normal cells due to lack of selectivity for the abnormal cells is well noticeable. With the rapid development of cell biology and molecular biology, the strategy of anti-cancer drug research has shifted to new and more selective targets for cancer cell proliferation, such as cancer cell signal transduction pathways, growth factors and their receptors, and apoptosis pathway. Therefore, the search for anticancer agents has been in continuum for many years.

Nevertheless, targeted therapy has some limitations; the chief among them is the potential for the cells to develop resistance. Unfortunately, in most cases, another targeted therapy that could overcome this resistance is not available, so it is advantageous to use targeted therapy in combination, either with other targeted therapy or with traditional therapy $[25,26]$.

In this review, a literature survey on the anticancer activity of benzimidazole was illustrated. Various anticancer agents (also referred to as antitumor, antiproliferative, and antineoplastics) reported for treatment of varied kinds of cancers act through different mechanisms. Benzimidazole exerted their antitumor activity through versatile mechanisms of action such as DNA alkylation, DNA binding, disturbing tubulin polymerization or depolymerization, enzyme inhibition, antiangiogeneic, and signal transduction inhibitors.

\section{2-Substituted benzimidazoles as alkylating agents}

Alkylating agents are highly electrophilic compounds that react with nucleophilic groups on DNA, in particular the N-7 of G base, to form a strong covalent bond disrupting replication or transcription.

1,2,5-Trisubstituted benzimidazoles were found to act as alkylating agents, for example, bendamustine 1 $\left(\right.$ TREANDA $^{\circ}$ ), which has been approved by the FDA for the treatment of leukemia, multiple myeloma, and nonHodgkin's lymphoma [27, 28].

In addition, the pyrrolo[1,2-a]benzimidazoles-4,7diones $\mathbf{2 a - c}$ are one of the early classes of anticancer agents designed as new DNA cross-linkers acting through cleavages of $\mathrm{G}$ and $\mathrm{A}$ bases which possess $\mathrm{IC}_{50}$ ranging from 10 to $6000 \mathrm{nM}$ values against various human ovarian and colon cancer cell lines [29].

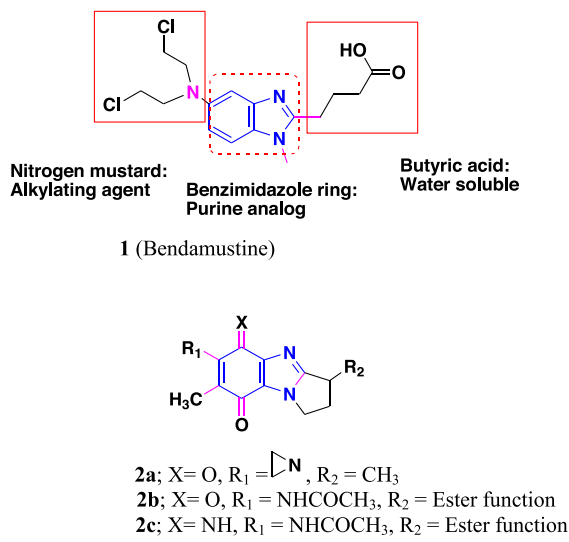

\section{Benzimidazoles as DNA-binding agents}

This class of compounds is known broadly as antimetabolites. These drugs inhibit the enzymes involved in the synthesis of nucleotide building blocks of DNA, resulting in the inhibition of DNA function which may lead to apoptosis [11].

Gao et al. synthesized 2-substiuted novel benzimidazole acridine subsidiaries keeping in setting that acridines can intercalate into DNA and benzimidazoles can tie in the DNA minor groove. MTT assay showed that most of the designed synthesized compounds revealed<smiles>CC(=O)Nc1ccc(C)cc1[N+](=O)[O-]</smiles><smiles>CC(=O)Nc1ccc(C)cc1N</smiles><smiles>Cc1ccc2[nH]c(C)nc2c1</smiles>

Scheme 1 Intramolecular cyclocondensation 


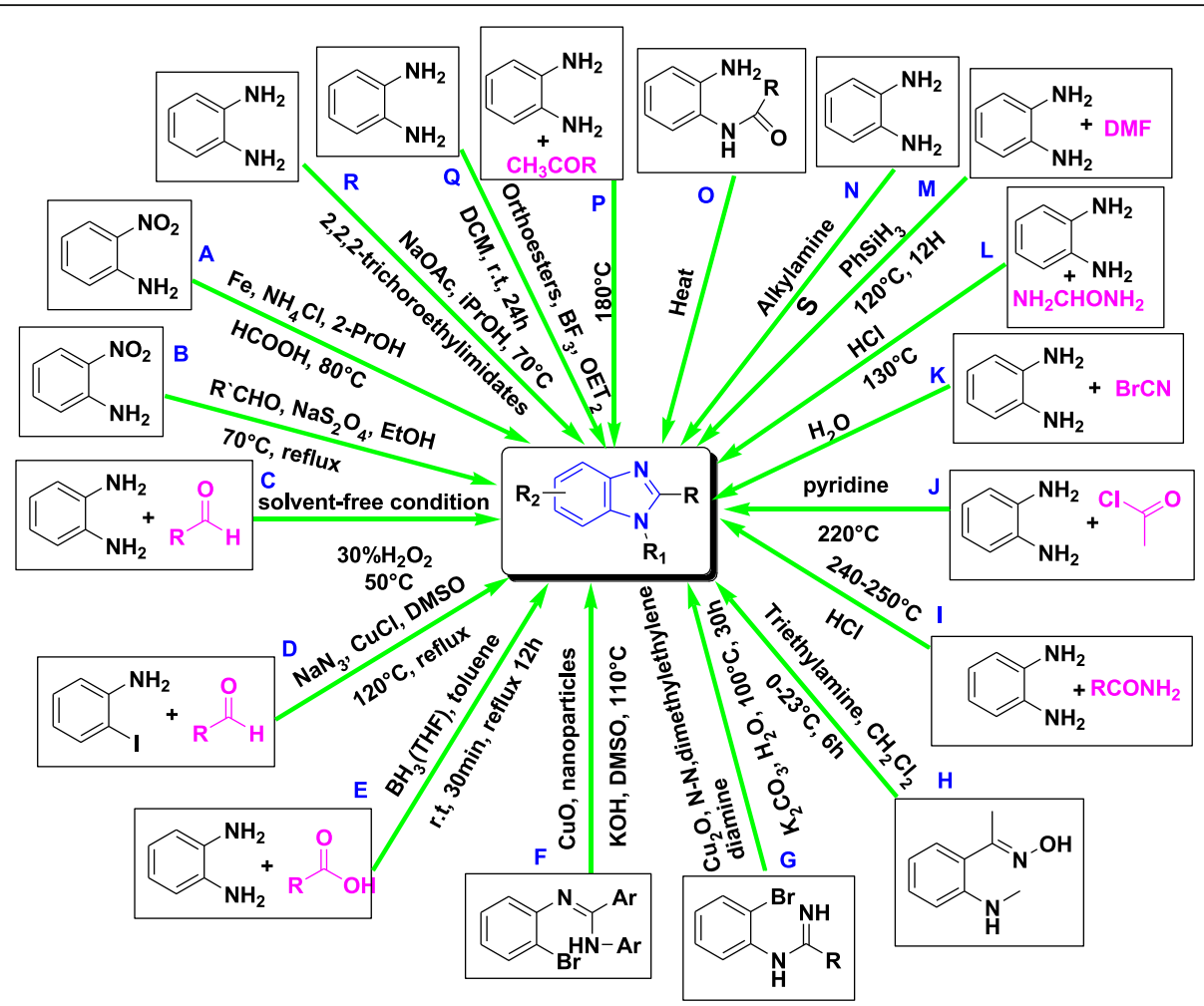

Scheme 2 The synthetic pathways of 2-substituted benzimidazole derivatives

great antiproliferative action, among which compound 3 exhibited high potency against both chronic myelogenous leukemia K562 and liver HepG2 cells [30].

2,6-Disubstituted benzimidazole-oxindole conjugate derivatives were synthesized by Nayak et al. furthermore, investigated the apoptotic system initiated by these conjugates against human breast cancer cell line, MCF- 7 . Following evaluation, compounds $\mathbf{4 a}$ and $\mathbf{4 b}$ showed $43.7 \%$ and $43.6 \%$ and $64.8 \%$ and $62.7 \%$ apoptosis, respectively, at 1 and $2 \mu \mathrm{M}$ concentrations [31].

On the other hand, the 5-substituted bisbenzimidazoles Hoechst 33258 (5a) and Hoechst 33342 (5b) were designed as DNA minor groove-binding agents. They displayed in vitro antitumor activities and nonspecifically inhibit the catalytic proliferation of DNA enzymes [32].

Derivatives of 1,2,5-trisubstitued 1-(4-methoxyphenethyl)-1H-benzimidazole-5-carboxylic acid were prepared and assessed as potential chemotherapeutic agents by Gowda et al. Among synthesized analogs methyl 1(4-methoxyphenethyl)-2-(4-fluoro-3-nitrophenyl)-1Hbenzimidazole-5-carboxylate 6 provoked cell death in leukemic cells with an $\mathrm{IC}_{50}$ of $3 \mu \mathrm{M}$. Additionally, it stimulates S/G2 cell cycle arrest, and downregulation of cyclin B1, CDK2, and PCNA. Moreover, the replacement of fluorine and nitro with amine, chlorine, or bromine reduced the activity as shown by the SAR study [33].
Hranjec et al. designed and synthesized benzimidazo[1,2-a]quinolones candidates that have the capacity to be incorporated into the space between the DNA base pairs resulting in DNA cleavage. All compounds exerted pronounced antiproliferative activity on five tumor cell lines, whereby compound 7 exerted the highest activity on all cell lines $\left(\mathrm{IC}_{50}=\right.$ $0.7-25 \mu \mathrm{M})$ and showed a special selectivity towards HeLa cells [34].

Recently, more 1,2-fused planar benzimidazole derivatives have been reported to exhibit potent cytotoxicity, for example, (pyrimidobenzimidazolone) 8 with in vitro NSCLC growth \% from -2.92 to 38.33 and $\mathrm{GI}_{50}$ ranges from -6.13 to $-4.82 \mu \mathrm{M}$. Compound 9 (1,3-diarylpyrazino benzimidazole) exhibited in vitro \% inhibition of lipid peroxidation (AAPH); interaction \% with DPPH (2, 2-diphenyl-1-picrylhydrazyl)and in vitro $\%$ inhibition of soybean lipoxygenase (LOX \% inh) was found to be 84 , $5,19 \%$, respectively $[35,36]$.

Zhou et al. developed and synthesized a new $\mathrm{Cu}(\mathrm{II})$ complex of benzimidazoles $\mathbf{1 0}$ possessed antitumor activity. The results suggested that the complex could electrostatically bind to the phosphate group of DNA backbone and partially intercalate into the double helix of DNA because of the bulky structure of the complex and the planarity of the benzimidazole rings [37]. 


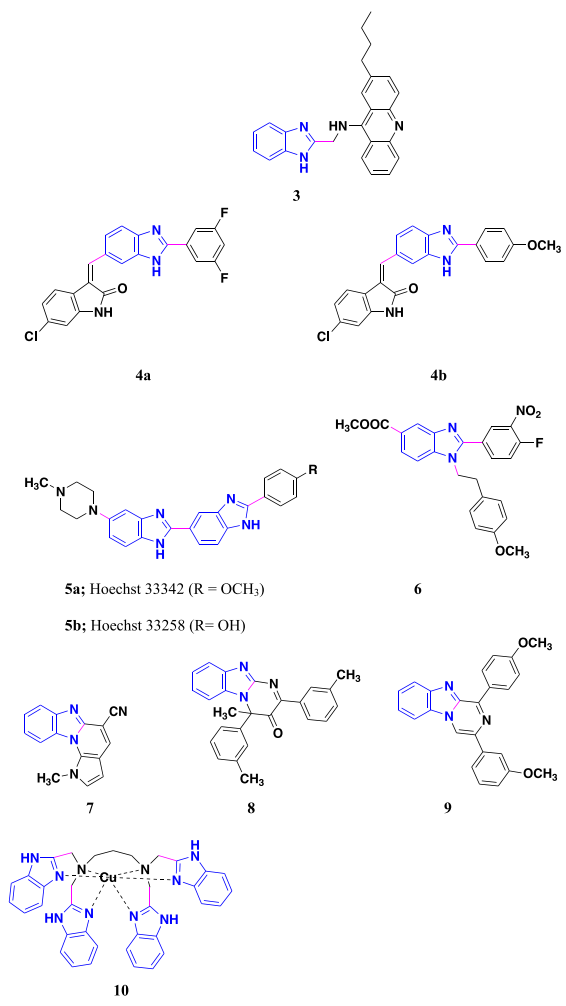

\section{2-Substituted benzimidazoles as tubulin inhibitors}

Microtubules are the key components of the cytoskeleton of eukaryotic cells composed of $\alpha / \beta$-tubulin heterodimers. They are involved in intracellular migration and transport. Tubulin inhibitors thus act by interfering with the dynamics of microtubules, i.e., growing (polymerization) and shortening (depolymerization). Either way, it leads to mitotic arrest and cell death [38-40].

Lu et al. outlined the synthesis and assessment of a series of tubulin inhibitors. Structure-activity relationships of these compounds prompted recognizable proof of new 2,4-disubstituted benzimidazole and imidazo(4,5-c)pyridine-fused ring templates, represented by compounds 11 and 12, respectively. Compound 11 enhanced the metabolic stability in liver microsomes and was the most active of the series with $\mathrm{IC}_{50}$ $0.022 \pm 0.009 \mu \mathrm{M}$ and $0.025 \pm 0.004$ against prostate tumor cell PC-3 and melanoma cancer cell A375, respectively [41].

Kamal et al. identified a series of 2,6-disubstituted pyrazolyl benzimidazole analogs as microtubule-destabilizing agents where they showed potent growth-inhibitory activity against most of the sixty cancer cell line panels of NCI ranging from 0.3 to $13 \mu \mathrm{M}$. A549 cells treated with $\mathbf{1 3 a}-\mathbf{c}$-arrested cells at the $\mathrm{G} 2 / \mathrm{M}$ phase apart from activating cyclin-B1 protein levels and disrupting the microtubule network. Moreover, these conjugates adequately hindered tubulin polymerization with $\mathrm{IC}_{50}$ values of $1.3-3.8 \mu \mathrm{M}$. Compound $\mathbf{1 3 b}$ with a methoxy substituent showed obvious cytotoxic potential and incited activity right around 3-fold higher than CA-4 [42].
2,5-Disubstituted novel benzimidazole carbamates linked with indole moieties by sulfur or selenium atoms were synthesized and examined for their inhibitory action against some human cancer cell lines. Among these, compound 14 was identified as the most active antitumor against HT-1080, A-549, and SGC-7901 human cancer cell lines with $\mathrm{IC}_{50}$ values ranging from 0.098 to $0.15 \mu \mathrm{M}$. In vitro tubulin polymerization assay revealed that 14 significantly detains tubulin polymerization and upsets tubulin microtubule. Also, a molecular modeling study exhibited that compound $\mathbf{1 4}$ bonds with a coupling mode similar to that of nocodazole [43].

Analogs of 2,5-disubstituted benzimidazoles were developed and assessed for their tubulin inhibitory activity. Compound $\mathbf{1 5}$ strongly restrained the proliferation of a panel human cancer cells, with $\mathrm{IC}_{50}$ values ranging from 0.006 to $1.774 \mu \mathrm{M}$; also it prompted cell cycle arrest at the $\mathrm{G} 2 / \mathrm{M}$ phase [44].

2,4/5-Disubstituted class of terphenyl benzimidazoles 16a,b were designed and synthesized as tubulin polymerization inhibitors. 16a,b demonstrated significant anticancer activity with $\mathrm{GI}_{50}$ ranges from $<0.1$ to $2.11 \mu \mathrm{M}$. These compounds exhibit G2/M phase arrest; besides the analysis of tubulin by western blot, experiments were carried out revealing a concomitant decrease in the polymerized tubulin [45].

Wang et al. designed some 1,2-disubstituted benzimidazole derivatives as potential tubulin polymerization inhibitors and anthropic cancer cell line cytotoxic agents. Compound 17 was established as the most potent tubulin polymerization inhibitory agent with $\mathrm{IC}_{50}$ of $1.5 \mu \mathrm{M}$ and exhibited antiproliferative activity against several human cancer cell lines [46].
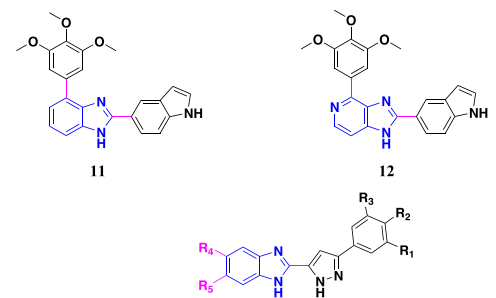

$$
\begin{aligned}
& \text { 13a; } \mathrm{R}_{1}=\mathrm{OCH}_{3}, \mathrm{R}_{2}=\mathrm{OCH}_{3}, \mathrm{R}_{3}=\mathrm{OCH}_{3}, \mathrm{R}_{4}=\mathrm{H}, \mathrm{R}_{5}=\mathrm{H} \\
& \text { 13b; } \mathrm{R}_{1}=\mathrm{OCH}_{3}, \mathrm{R}_{2}=\mathrm{OCH}_{3}, \mathrm{R}_{3}=\mathrm{OCH}_{3}, \mathrm{R}_{4}=\mathrm{H}, \mathrm{R}_{5}=\mathrm{OCH}
\end{aligned}
$$
$13 \mathbf{c} ; \mathrm{R}_{1}=\mathrm{OCH}_{3}, \mathrm{R}_{2}=\mathrm{OCH}_{3}, \mathrm{R}_{3}=\mathrm{OCH}_{3}, \mathrm{R}_{4}=\mathrm{H}, \mathrm{R}_{5}=\mathrm{Cl}$

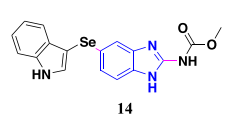

14

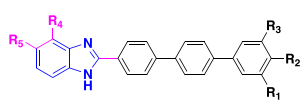

$\begin{array}{lllll}\mathbf{R}_{1} & \mathbf{R}_{2} & \mathbf{R}_{3} & \mathbf{R}_{4} & \mathbf{R}_{5}\end{array}$ $16 \mathbf{a}=\mathrm{OCH}_{3}, \mathrm{OCH}_{3}, \mathrm{OCH}_{3}, \mathrm{OH}, \mathrm{H}$ 16 $\mathbf{b}=\mathrm{OCH}_{3}, \mathrm{OCH}_{3}, \mathrm{OCH}_{3}, \mathrm{H}, \mathrm{CH}_{3}$
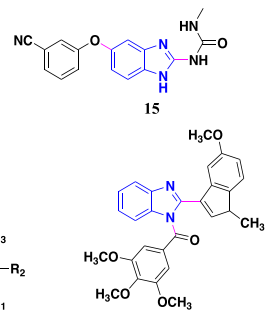
2-Substituted benzimidazoles as enzyme inhibitors 2-Substituted benzimidazoles as sirtuin inhibitors Sirtuins are class III histone deacetylases (HDACs) that catalyze the deacetylation of proteins. They focus on an extensive variety of cell proteins in the nucleus, cytoplasm, and mitochondria [47, 48]. It has been reported that SIRT1 and SIRT2 are upregulated in numerous tumor sorts and they are able to inactivate some tumor suppressor proteins [49]. Therefore, the development of novel sirtuin inhibitors has been proposed as another line in the treatment of cancer $[50,51]$.

Yoon et al. developed novel 1,2,5-trisubstituted benzimidazole derivatives as SIRT1 and SIRT2 inhibitors. Compound 18 showed the best inhibitory activity for SIRT1 $\left(\mathrm{IC}_{50}=54.21 \mu \mathrm{M}\right)$ and for SIRT2 $\left(\mathrm{IC}_{50}=\right.$ $26.85 \mu \mathrm{M})$. Cell proliferation assay demonstrated that compound 18 had pronounced antitumor activity against three different types of cancer cells (breast MDA-MB-468, colon HCT-116, and blood-leukemia CCRF-CEM). The SAR study verified that the replacement of the phenyl group at position N1 led to a loss of activity [52].

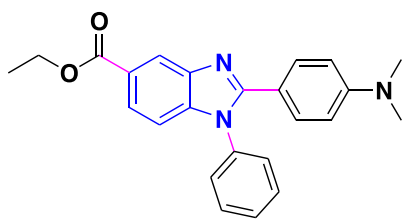

18

\section{2-Substituted benzimidazoles as poly (ADP-ribose) polymerase inhibitors}

Poly (ADP-ribose) polymerase-1 (PARP-1) is a key DNA damage-sensing enzyme that facilitates the repair of DNA. PARP-1 contributes to the resistance that often develops after cancer therapy. Consequently, it is assumed that in vivo inhibition of PARP will block DNA repair and increase the maximum therapeutic benefit of chemotherapy [53].

Some 2,4-disubstituted benzimidazoles were demonstrated to have PARP inhibitory activity. Penning et al. reported the design of a new series of 2substituted-1H-benzimidazole-4-carboxamides. Especially, compound 19 Veliparib (ABT-888) displayed great adequacy against both the PARP-1 and PARP-2 enzymes with a $K_{\mathrm{i}}$ (inhibitory constant and reflective of the binding affinity) of $5 \mathrm{nM}$ and in a C41 wholecell assay with an $\mathrm{EC}_{50}$ of $2 \mathrm{nM}$ and exhibited potentiation of two cytotoxic agents in particular temozolomide and cisplatin in both mouse melanoma and breast cancer demonstrate [54].

Abdullah et al. prepared different 2,4,6-trisubstituted benzimidazole derivatives and studied their activity as dual Poly (ADP-ribose) polymerases (PARPs) and Dihydroorotate dehydrogenase (DHODH) inhibitors. Analogs 20a-d were proven to be the most potent compounds of the series with $\mathrm{IC}_{50}$ ranges from $0.013-55$ to $0.061-44 \mu \mathrm{M}$ against $\mathrm{DHODH}$ and PARPs, respectively [55].

A series of novel 2,4,5-trisubstituted benzimidazole analogs were identified and evaluated for their PARP1 inhibitory activity by Wang et al. All target compounds demonstrated high intrinsic PARP-1 inhibitory activity and have been assessed for in vitro cellular assays to evaluate the potentiation effect of cytotoxic agents against cancer cell lines. Compound 21 showed strong inhibition against the PARP-1 enzyme with an $\mathrm{IC}_{50}$ of $43.7 \mathrm{nM}$, excellent cell inhibitory activity in HCT116 cells $\left(\mathrm{IC}_{50}=7.4 \mu \mathrm{M}\right)$, and potentiation of temozolomide cytotoxicity in the cancer cell line A549 $\left(\mathrm{PF}_{50}=1.6\right)$ [56].

Zhou et al. synthesized several derivatives of 2substituted-3,4-fused benzimidazole carboxamide as PARP-1 inhibitors, which can be $18 \mathrm{~F}$-labeled easily for positron emission tomographic (PET) imaging. Of the compounds synthesized, 22 had the highest inhibition potency for PARP-1 with $\mathrm{IC}_{50} 6.3 \mathrm{nM}$ [57].

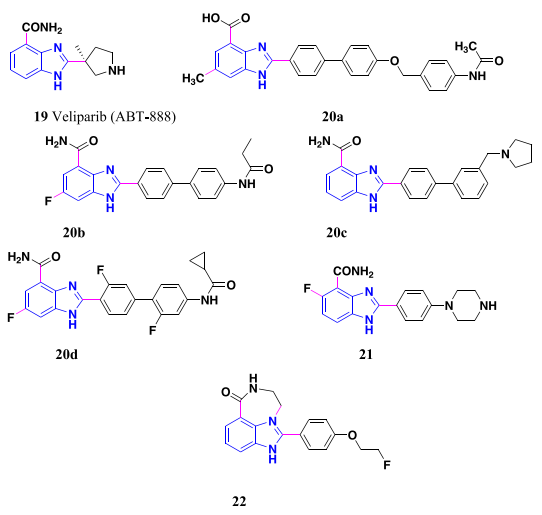

\section{2-Substituted benzimidazoles as methionine synthase inhibitors (MetSIs)}

Enzyme methionine synthase catalyzes the transfer of a methyl group from 5-methyltetrahydrofolate to homocysteine, to obtain methionine and tetrahydrofolate; thus, inhibition of methionine synthase (MetS) would settle DNA and RNA [58].

One of the most potent inhibitors of MetS was 2,5-disubstituted benzimidazole 23 which showed $\mathrm{IC}_{50}$ of $50 \pm$ $5 \mu \mathrm{M}$ with a score of the lowest free energy of binding $1610.42 \mathrm{~kJ} / \mathrm{mol}[59]$.

Other 2,5-disubstituted benzimidazole derivatives were designed and evaluated for their inhibitory activity against purified rat liver methionine synthase using a radiometric enzyme assay. Compounds 24a,b were proven to be the most powerful compounds, with 
$\mathrm{IC}_{50}$ values of $20 \mu \mathrm{M}$ and $18 \mu \mathrm{M}$, respectively. Modeling and docking studies determine the molecular requirements of the activity of this class of compounds [60].

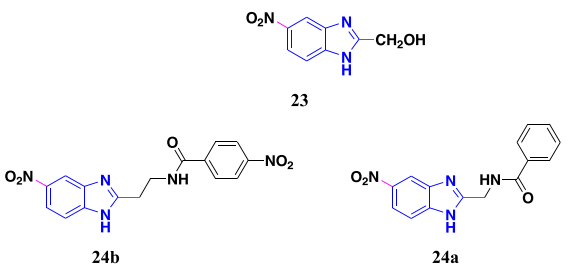

\section{2-Substituted benzimidazoles as DHFR inhibitors}

Dihydrofolate reductase (DHFR) is a critical enzyme in folate metabolism. It converts dihydrofolate (DHF) to tetrahydrofolate (THF), which is essential for purine and thymidylate (TMP) synthesis in cell proliferation. Depressing DHFR activity results in THF deficiency and disruption of subsequent DNA replication and resulting in cell death.

A new series of 1,2,6-trisubstituted triazinebenzimidazole hybrid was developed as a potent DHFRI. Compound 25 was found to be the most active DHFRI with $\mathrm{IC}_{50}$ of $1.05 \mu \mathrm{M}$. These findings are the outcome of their inhibitory activities tested over 60 human tumor cell lines, whereas 25 revealed a broad spectrum of antitumor activities with a $\mathrm{GI}_{50}$ value of $9.79 \mu \mathrm{M}[11,61]$.

Recently, Singla et al designed and synthesized novel series of 1,2,6-trisubstituted quinazolin-4-onebenzimidazoles. As per the results of dihydrofolate reductase enzyme immunoassay, compound 26 exhibited comparable activity with $\mathrm{IC}_{50}$ value of $0.011 \mu \mathrm{M}$ in contrast to methotrexate $\left(\mathrm{IC}_{50}=0.02 \mu \mathrm{M}\right)$. The preparatory interactive examinations with calf thymus DNA by UV-visible and fluorescence spectroscopy disclosed that compound 26 was viably intercalated with ct-DNA [62].

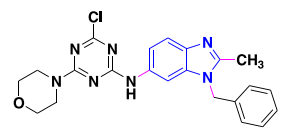

25

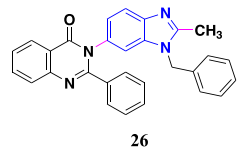

26

\section{2-Substituted benzimidazoles as topoisomerase I and II inhibitors}

Topoisomerase enzymes are a family of enzymes which catalyze the cleavage, annealing, and supercoiling of DNA and considered a major target for antineoplastic agents used in the treatment of breast, lung, and prostate cancer, sarcomas, and hematological malignancies. All topoisomerase IIdirected agents are able to interfere with at least one step of the catalytic cycle $[63,64]$.
2-Substituted benzimidazole derivatives 27a,b were synthesized and screened against topoisomerase I with inhibition percent $95.4 \%, 90.2 \%$, respectively. Meanwhile, the cytotoxic activity against HeLa (cervix adenocarcinoma), MCF7 (breast adenocarcinoma), and A431 (skin epidermoid carcinoma) cells were measured, the $\mathrm{IC}_{50}$ were found to range from 6.04 to $>30 \mu \mathrm{M}$ [65].

A series of new pyrazolo[3,4-d]pyrimidine possessing 4-(1H-benzimidazol-2-yl)-phenylamine moiety has been designed and synthesized by single et al. Compounds 28, 29, 30, and 31 turned out to be the most efficacious candidates in this series, with mean $\mathrm{GI}_{50}$ values of $1.30 \mu \mathrm{M}, 1.43 \mu \mathrm{M}, 2.38 \mu \mathrm{M}$, and $2.18 \mu \mathrm{M}$, respectively, against several cancer cell lines. Moreover, these compounds induced apoptosis and suppressed human topoisomerase (Topo) II $\alpha$. These discoveries established a framework for the sound outline of powerful agents for probing proteins, which are relied upon to give vital knowledge into the field of DNA and protein connections [66].

In a study of some novel fused heterocyclic compounds as eukaryotic topisomerase II inhibitors. It was discovered that 5-methylcarboxylate-2-phenylthiomethylbenzimidazole, 32, with $\mathrm{IC}_{50} 17 \mu \mathrm{M}$ was more active than the reference drug etoposide $\left(\mathrm{IC}_{50}=21.8 \mu \mathrm{M}\right)$ [67].

Singh et al. worked on the synthesis of a novel class of topoisomerase I inhibitor as 2-aryl-5-substituted-2,5-bisbenzimidazole derivatives. Analogs 33a,b were found to be with the highest ability to induce DNA cleavage with $\mathrm{IC}_{50}$ in the micromolar range (0.6-5.5) against U87, MCF7, and HeLa human tumor cells. The SAR study revealed that the introduction of halogen groups at the phenyl ring increased the binding affinity to ct-DNA particularly fluoro and chloro groups which showed significant cytotoxic activity to human tumor cell lines [68].

Jin et al. prepared a series of heterocyclic derivatives of 5-phenyl-bibenzimidazoles, 34, and assessed them for their topoisomerase I poisoning activity and cytotoxicity. It was concluded that topoisomerase I poisoning activity was related to analogs that had a hydrogen atom capable of hydrogen bond formation, thus influencing the activity [69].

A new $\mathrm{Cu} 2+$ complex of 2-pyridinylbenzimidazole5-carboxylic acid analogs were designed and prepared by Galal et al. Among all, compound 35 was found to be the most potent candidate inhibiting the topoisomerase II on the DNA-relaxing activity of P388 topoisomerase II with $\mathrm{IC}_{50} 2.5 \mu \mathrm{M}$. Meanwhile, the growth-inhibitory effects of the tested compounds on 21 human solid tumor cell lines (8 lung, 7 colon, and 6 gastric cancer cell lines) with mean $\mathrm{GI}_{50}=$ $0.091 \mu \mathrm{M}[70]$. 

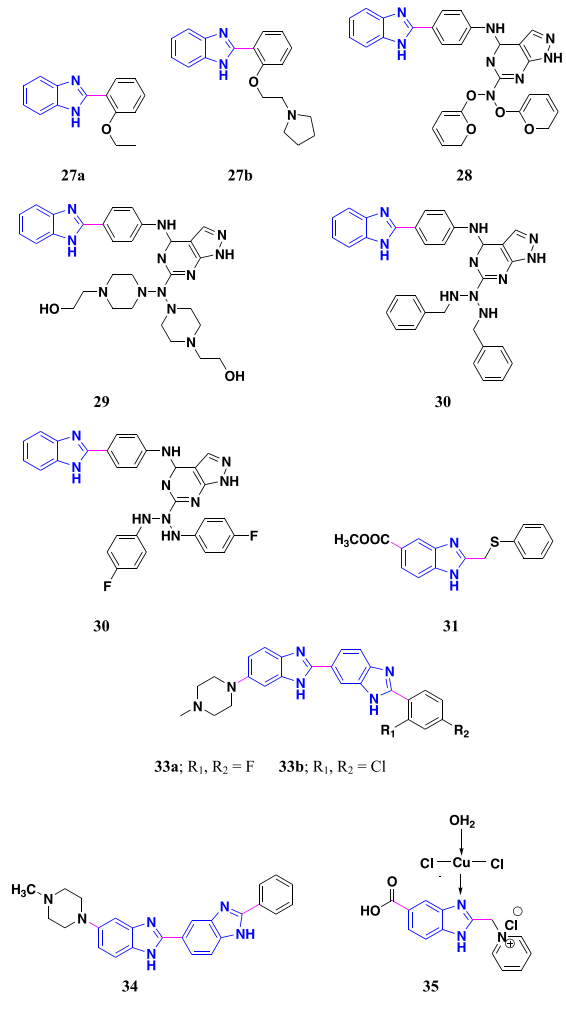

\section{2-Substituted benzimidazoles as androgen receptor activity antagonists}

Testosterone and dihydrotestosterone control protein anabolism and influence basal metabolism through the upregulation of the androgen receptor. Although androgens have numerous valuable impacts and are critical for sexual orientation and male advancement, endogenous androgens, for example, testosterone fortify hyperplasia of the prostate and intensify androgen-subordinate prostate disease [71].

Elancheran et al. designed and synthesized a series of 1,3,5-tri-substituted 2-oxobenzimidazoles derivatives and investigated them as androgen receptor antagonistic activity. It can be concluded that compound $\mathbf{3 6}$ is the most active compound from the series against prostatic $\mathrm{PC}-3$ and LNCaP cancer cell lines [72].

$\mathrm{Ng}$ et al. have investigated some 1,2,5,6-tetrasubstituted benzimidazoles as androgen receptor antagonists for their utilization in prostate malignancy. The SAR studies have prompted the 1-(4-bromobenzyl) derivative 37 as the most intense androgen receptor opponent which has an $\mathrm{ID}_{50}$ of $0.13 \mathrm{mg} /$ day [73].

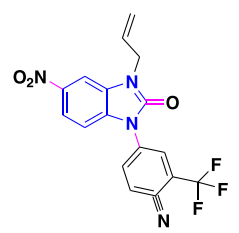

36

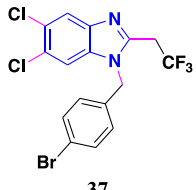

37
2-Substituted benzimidazoles as a-glucosidase inhibitors $\alpha$-Glucosidase inhibitors have wide biological significance as chemotherapeutic agents for the treatment of carbohydrate mediated diseases such as diabetes and cancer [74].

Consequently, 2,5,6-trisubstituted benzimidazoles bearing thiourea moiety have been synthesized and assessed for $\alpha$-glucosidase inhibition using Baker's yeast $\alpha$ glucosidase enzyme. All tested compounds exhibited variable $\alpha$-glucosidase inhibitory activity, while compound 38 showed significant inhibitory effects with an IC50 value of $35.83 \pm 0.66 \mu \mathrm{M}$, which was more potent than the standard acarbose (IC50 $=774.5 \pm 1.94 \mu \mathrm{M})$ [75].

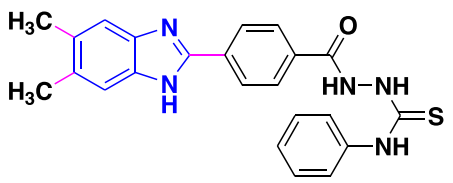

38

\section{2-Substituted benzimidazoles as the G9a histone methyltransferase inhibitors}

G9a is initially identified as a H3K9 methyltransferase that specifically mono- and dimethylates "Lys-9" of histone H3 (H3K9me1 and H3K9me2, respectively) in euchromatin. Histone lysine methylation plays a central epigenetic role in the organization of chromatin domains and the regulation of gene expression [76]. Mutation and amplification of HMTs are frequently observed in human cancers and employed as a promising target in cancer therapy [77].

Recently, 1,2,5-trisubstituted benzimidazole scaffold was discovered as G9a histone methyltransferase inhibitor by Zhang et al. Based on structure optimization, 24 structural analogs are designed and synthesized. The kinase inhibition assay showed that compound 39 potently inhibits G9a with an $\mathrm{IC}_{50}$ of $1.32 \mu \mathrm{M}$. Besides, the MTT assay revealed that MCF-7 is most sensitive to 39 among five different breast cancer cells with $\mathrm{IC}_{50} 5.73 \pm$ 0.95 . In addition, compound 39 induces obvious autophagy in MCF7 cells by fluorescence microscope assays and western blot analysis [78].

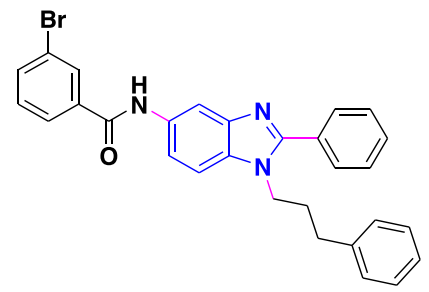

39

\section{2-Substituted benzimidazoles as pyruvate kinase inhibitors}

Recently, the role of the M2 isoform of pyruvate kinase in the change in cellular metabolism to aerobic glycolysis has been proposed [79]. Tumor cells entirely express the 
embryonic M2 isoform of pyruvate kinase (PKM2); the dimeric form assists cell growth by increasing glycolytic intermediates for biosynthetic processes, but when energy levels decrease, the enzyme shifts to the tetrameric form and makes oxidative phosphorylation easy [80].

Consequently, the discovery of 1,2-disubstituted benzimidazole series was described as potent and selective PKM2 activators by Guo et al.; Compound $\mathbf{4 0}$ was reported to have appreciable inhibitory activity against PKM2 cancer cells with a lactate dehydrogenase (LDH) $\mathrm{IC}_{50}$ value of $3.5 \mu \mathrm{M}[81]$.

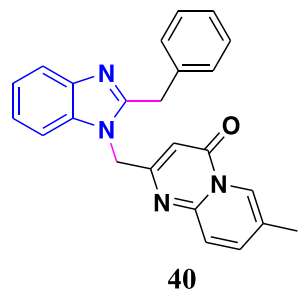

2-Substituted bisbenzimidazoles as telomerazse inhibitors Maji et al. reported a new series of 2,6-disubstituted bisbenzimidazole-carbazoles and was evaluated for their antiproliferative activity as telomerase inhibitors where compound 41 was recognized as the most potent derivative with an $\mathrm{IC}_{50}$ value of $0.6 \pm 0.01 \mu \mathrm{M}$ [82].

Similarly, 2-substituted tribenzimidazole derivatives were synthesized and evaluated for their telomerase inhibitory properties. Compound $\mathbf{4 2}$ was found to be the most active compound of the series [83].

In addition, compounds 43a-c are derivatives of 2substituted-5,6-fused benzimiadzole that exhibited in vitro inhibition of hTERT expression, telomerase inhibition, and suppression of prostatic cancer cell growth with $\mathrm{IC}_{50}$ values 5.1 to $27.9 \mu \mathrm{M}$ [84].

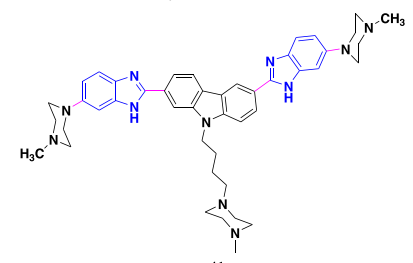

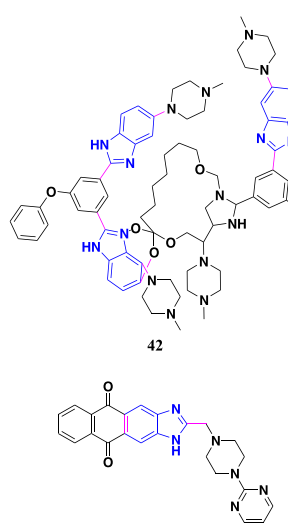

43b

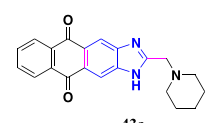

43a

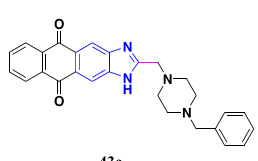

$43 \mathrm{c}$
2-Substituted benzimidazoles as antiangiogenic agents and signal transduction inhibitors

Tumor growth and development of distant metastasis are supported through angiogenesis where new blood vessels extend from pre-existing ones. This process is mediated via the vascular endothelial growth factor (VEGF) which links to its receptor tyrosine kinase (RTK) to advance the proliferation and survival of endothelial cells. Consequently, using kinase inhibitors to adjust VEGFR signaling is considered as a powerful method for the inhibition of tumor angiogenesis [85, 86].

Protein kinases regulate most aspects of normal cellular function, especially signals transduction from the cell membrane into the interior of the cell [87]. Signal transduction relates to the methods by which regulatory molecules that control essential processes of cell growth and differentiation, convey within the cell. Most malignancies have abnormal or overexpressed signal transduction factors which depend on the kinase enzymes thus recommending them as targets for therapeutic progress $[88,89]$.

A large number of benzimidazoles were reported to possess protein kinases inhibitory activity [90].

\section{2-Substituted benzimidazoles as VEGFR inhibitors}

Keeping this in mind, 2-substituted benzimidazole analogs were prepared and assessed for their in vivo antitumor and antiangiogenic activities. Compounds $\mathbf{4 4}$ and 45 showed cytotoxic effects on MDA-MB-31 cells and HUVEC with $\mathrm{IC}_{50}$ value ranges from 0.40 to $6 \mu \mathrm{M}$ and from 0.05 to 1.5 , respectively, and effectively antagonized VEGF- $\mathrm{A}_{165} / \mathrm{NRP}-1$ binding [91].

In addition, a series of 2,5/6-disubstituted benzimidazole derivatives were developed as potent VEGFR-2 (KDR) kinase inhibitors. Among them, compound 46 showed the most potent VEGFR-2 inhibitory activity with an $\mathrm{IC}_{50}$ value of $0.03 \mu \mathrm{M}$ and it also demonstrated strong anticancer activity against the tested cancer cell lines [85].

Temirak et al. identified 1-aryl,2-furyl benzimidazoles and tested their anti-cancer activity where compound $\mathbf{4 7}$ showed the most potential antiangiogenic effect against VEGFR2 kinase with an $\mathrm{IC}_{50}$ value of $6.98 \mu \mathrm{g} / \mathrm{mL}$ [92].

A novel series of 1,2-disubstituted benzimidazol-furan hybrids were designed, synthesized, and evaluated for their in vitro cytotoxic activity against breast (MCF-7) and hepatocellular (HepG2) carcinoma cell lines 48a,b, 49-51. Two of the synthesized conjugates, $\mathbf{4 8 b}$ and $\mathbf{4 9}$, showed potent antiproliferative properties against the MCF-7 cell line $\left(\mathrm{IC}_{50}=21.25\right.$ and $21.35 \mu \mathrm{M}$, respectively). Additionally, compounds 48a,b, 50, and $\mathbf{5 1}$ showed promising potency $\left(\mathrm{IC}_{50}=25.95,22.58,26.94\right.$, and $31.06 \mu \mathrm{M}$, respectively) against the liver carcinoma cell line HepG2. Meanwhile, the in vitro evaluation on 
VEGFR-2 in the MCF-7 cell line showed their potent inhibitory activity ranges from 92-96\%, compound 48a was found to have promising VEGFR-2 inhibitory activity $\left(\mathrm{IC}_{50}=0.64 \mu \mathrm{M}\right)$ [93].

Novel conjugates of 2,5,6-trisubstituted benzimidazoles were synthesized and examined against VEGFR-1 and VEGFR-2. Compound 52 displayed VEGFR-2 inhibitory activity with a $50 \%$ inhibition concentration value as low as $0.02 \pm 0.03 \mu \mathrm{M}$. VEGFR-2 active compounds display good activity against VEGFR-1 up to $91 \%$ inhibition at $10 \mu \mathrm{M}$ concentration. The compounds likewise give a chance of establishing the framework for promising molecules of anticancer activity [94].

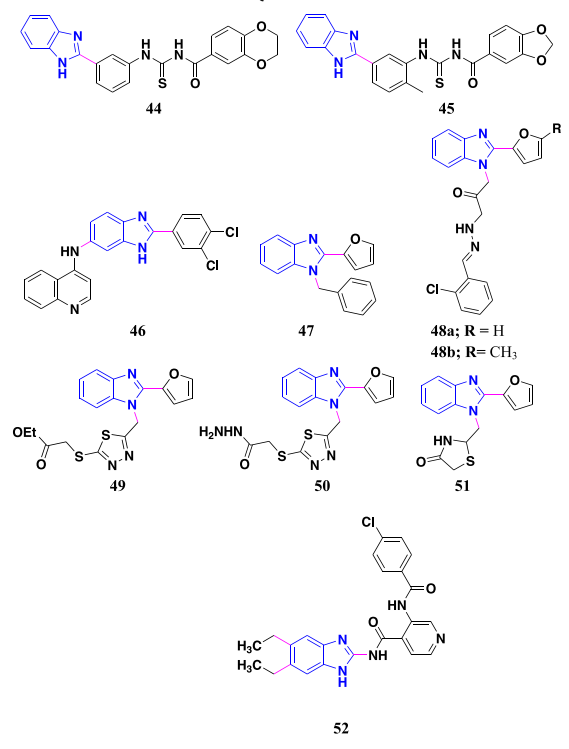

\section{2-Substituted benzimidazoles as EGFR inhibitors}

The EGFR (also known as erbB1 or HER1) and the related human epidermal growth factor receptor HER2 (also known as erbB2) is an encouraging aim for anticancer drug design because of its value in tumor growth, metastasis, and angiogenesis [95-98].

Akhtar et al. identified the synthesis of oxadiazole attached to benzimidazole at position $\mathrm{C}_{2}$ as potential EGFR and erbB2 receptor inhibitors and assessed their cytotoxic activity. The most active compounds against breast cancer cell lines constitute para-substituted chloro/methoxy phenyl at the fifth position of oxadiazole 53a,b, while, derivative 53a specifically affected cell cycle arrest at $G_{2} / M$ phase with an increase in apoptosis. Also, it inhibited EGFR and erbB2 receptor at 0.081 and $0.098 \mu \mathrm{M}$ concentration [99]. A series of 1,2,7-trisubstituted benzimidazole derivatives were developed and evaluated for mutant non-small-cell lung cancer activity and epidermal growth factor receptor (EGFR) by Lelais et al. Compound $\mathbf{5 4}$ was proven to be the most powerful compound of the series against lung cancer cell lines [100].

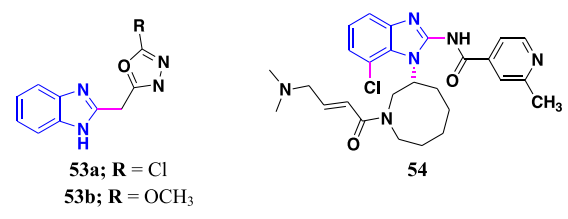

\section{2-Substituted benzimidazoles as FGFR1 inhibitors}

Fibroblast growth factor receptor (FGFR) represents an attractive oncology target for cancer therapy in perspective of its basic part in advancing tumor formation and progression, and additionally making resistance-affirmed treatments [101].

Yan et al. synthesized a series of 2,5-disubstituted benzimidazole and evaluated them for effective inhibition effect of the fibroblast growth factor receptor. Compound 55 was recognized as a potent pan-FGFR inhibitor and exhibited outstanding in vitro inhibitory activity against a panel of FGFR-amplified cell lines with $\mathrm{IC}_{50}<0.1 \mathrm{nM}$. Also, 55 gave almost total control of tumor development $(96.9 \%$ TGI) in NCI-H1581 (FGFR1-amplified) xenograft mice model [102].

New 2,6-disubstituted benzmidazoles were synthesized by Gryshchenko et al. and assessed for inhibition of FGFR1 kinase activity. Compounds 56a,b displayed the most potent activity with an $\mathrm{IC}_{50}$ value of $0.63 \mu \mathrm{M}$ and $0.32 \mu \mathrm{M}$ respectively. The SAR study showed that the presence of the hydroxyl group at the meta position of the benzene ring of 56a,b caused rapid augmentation of inhibition towards FGFR1 [103].
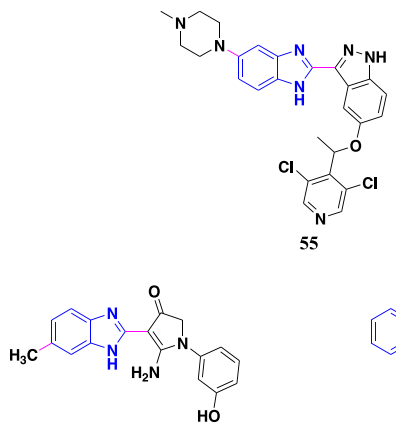

$56 \mathbf{a}$

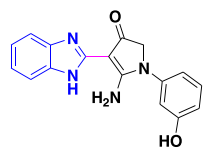

56b

\section{2-Substituted benzimidazole Tie-2 receptor tyrosine kinase inhibitors}

Tie-2 is a receptor tyrosine kinase that is essential for the formation of the embryonic vasculature and is strongly implicated in tumor angiogenesis [104].

Novel 2,5-disubstituted benzimidazolyl-4aminopyrrolopyrimidine analogs $\mathbf{5 7} \mathbf{a}, \mathbf{b}$ were identified as potent inhibitors of the Tie-2 kinase. Compound 57a with 2,6-di-fluoro-phenylsulfonyl group was discovered to have Tie-2 kinase and cellular (Caco-2BA/AB) $\mathrm{IC}_{50}$ of 568 and $518 \mathrm{nM}$, respectively. The corresponding urea analog compound 57b was more potent inhibitor against 
Tie-2 kinase cellular assays with $\mathrm{IC}_{50}$ of 241 and 112 $\mathrm{nM}$, respectively [87].

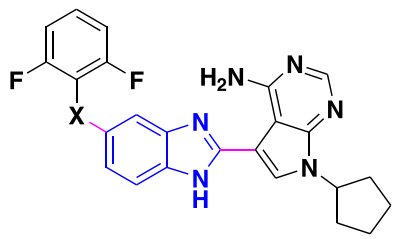

57a; $\mathrm{X}=\mathrm{NHSO}_{2}$

$\mathbf{5 7 b} ; \mathrm{X}=\mathrm{NHCONH}$

\section{2-Substituted benzimidazoles as heparanase inhibitors}

Heparanase is an endo $\beta$-D-glucuronidase that cleaves heparan sulfate polymers in the extracellular matrix and regulates the release of many growth factors that are involved in tumor invasion. The finding that heparanase is elevated in a variety of tumors and is subsequently linked to the development of pathological processes makes the inhibition of this enzyme a target for anticancer development programs [105].

Pan et al. incorporated a 2,5,6-trisubstituted bisbenzimdazole with urea derivatives and assessed their potential to suppress heparanase enzyme. Compound $\mathbf{5 8}$ revealed high heparanase inhibitory activity with $\mathrm{IC}_{50}$ ranging from $0.075-0.27 \mu \mathrm{M}$ [106].

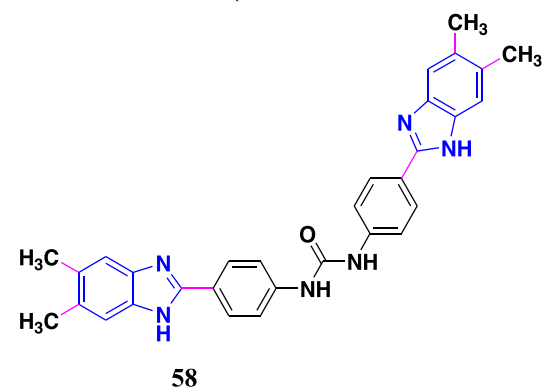

\section{2-Substituted benzimidazoles as COX-1 and COX-2 inhibitors}

In the aim of developing novel technique for cancer treatment, cyclooxygenase enzymes inhibitors was introduced [107]. Cyclooxygenase proteins (COX) are the principle organizers of prostaglandin (PG) biosynthesis from arachidonic acid. COX enzymes are classified principally into two isoforms: a constitutive form (COX-1) and an inducible form (COX-2). The COX-2 isoform was found to be excessively expressed in tough human malignancies, for example, breast cancer, bladder, prostate, and colon. The COX-2 enzyme plays a part in apoptosis control, by increasing angiogenesis [108].

In this context, new series of 2-substituted benzimidazole pyrazoles were prepared and evaluated for their antiproliferative activity against breast carcinoma (MCF7) and non-small cell lung cancer (A549) cell lines. Compound 59 was the most active against both A549 and MCF-7 cell lines with $\mathrm{IC}_{50}=8.46$ and $6.42 \mu \mathrm{M}$, respectively. Also, 59 is the most COX-2 selective compound among all synthesized derivatives; it showed inhibitory activity against COX-2 enzymes with $\mathrm{IC}_{50}=$ $0.10 \mathrm{Mm}$, S.I. $=104.67)$ compared with celecoxib (COX$2 \mathrm{IC}_{50}=1.11 \mu \mathrm{M}$, S.I. $\left.=13.33\right)$ [109].

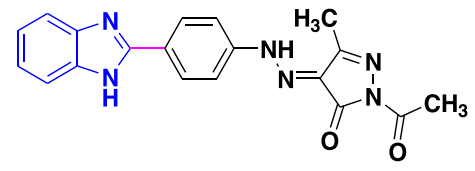

59

\section{2-Substituted benzimidazoles as Aurora A/B kinase inhibitors}

Aurora kinases are serine-threonine kinases that play a critical role in the mitotic events of cell division [110]. They are essential to secure the correct progress of cell cycle during mitosis or meiosis [111]. Different benzimidazoles have been developed as Aurora kinase inhibitors for cancer treatment.

Novel 2,6-disubstituted benzimidazole derivatives have been designed and synthesized as Aurora kinase inhibitors. The entire target compounds were determined against cancer cell lines U937, K562, A549, LoVo, and HT29 and were screened for Aurora A/B kinase inhibitory activity in vitro. Ccompound $\mathbf{6 0}$ demonstrated selective cancer cell line inhibitory activity towards U937, LoVo, and HT29 with $\mathrm{IC}_{50}$ values $3.821,1.422$, and $1.299 \mu \mathrm{M}$, respectively. In addition, 60 revealed high Aurora A/B kinase inhibitory activities ( $\mathrm{IC}_{50} 124.9$ and $191.0 \mathrm{nM})$ [112].

Compound 61, a 2-aminobenzimidazole derivative was identified and proven to act as potent Aurora kinase inhibitor with $\mathrm{IC}_{50}$ against Aurora $\mathrm{A} / \mathrm{B} 17$ and $5 \mathrm{nM}$, respectively. 2-Aminobenzimidazole acts as a bioisostere of the biaryl urea moiety of SNS-314, a potent Aurora kinase inhibitor, thus entered into the clinical study. This series of compounds present more aqueous solubility while keeping comparable potency in in vitro assays; compared with SNS-314, 61, in particular, has also exhibited a comparable profile to SNS-314 [113].

A novel 2,5-disubstituted benzimidazole (AT-9283) was described by Howard et al. as a multi-targeted kinase inhibitor, with special activity towards Aurora kinases A and B. Compound 62 (AT-9283) inhibited HCT116 cell line $\left(\mathrm{IC}_{50}=0.03 \mu \mathrm{M}\right)$ and demostrated the polyploid cellular phenotype characteristically related to Aurora $\mathrm{B}$ kinase inhibition ( $\mathrm{IC}_{50}$ of approximately 3 $\mathrm{nM})$. Compound $\mathbf{6 2}$ demonstrated in vivo efficacy in mouse xenograft models and is currently under evaluation in phase I clinical trials [114].

In an effort to identify novel compounds targeting Aurora kinase enzyme, Sharma et al. developed 1,2,5-trisubstituted benzimidazole derivatives. Among the 
several prepared compounds, 63 proved to be 1.25 -fold more active than the positive control 5-FU, with a $\mathrm{GI}_{50}$ value of $18.12 \mu \mathrm{M}$ (MG-MID). Moreover, interaction of the compound 48 with Aurora A enzyme showed selective inhibition of Aurora A kinase with $\mathrm{IC}_{50}$ value of $0.0 \mathrm{l}$ $\mu \mathrm{M}[115]$.

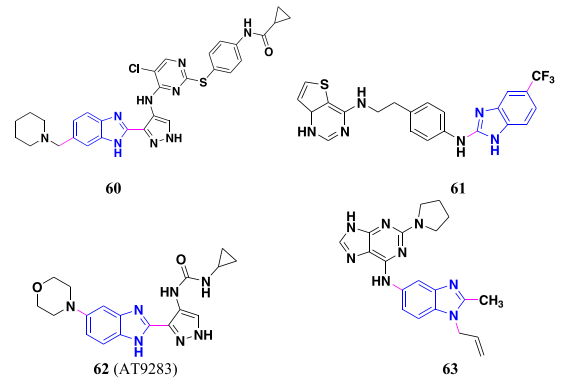

\section{2-Substituted benzimidazoles as checkpoint kinase (Chk1} and Chk2) inhibitors

Checkpoint kinase is a serine-threonine protein kinase that coordinates the DNA damage response and is activated by phosphorylation prompting cellular response such as cell cycle regulation, DNA repair, or apoptosis. ChK proteins are invariably more abundant in tumors as compared with normal tissues [116]. Inhibition of Chk2 has been proposed to be a significant argument of current cancer therapies $[117,118]$.

A series of 2/2,5-disubstituted benzimidazole derivatives was designed and synthesized by Song et al. as inhibitors of checkpoint kinase 1 (Chk1). Most of them exhibited moderate to good Chk1 inhibitory activities. Among them, compounds $\mathbf{6 4 a - c}$ showed significant Chk1 inhibitory activities with $\mathrm{IC}_{50}$ values of $4.05,6.23$, and $2.33 \mathrm{nM}$, respectively [119].

Some 2-substituted benzimidazoles were reported by $\mathrm{Ni}$ et al. as a novel class of small molecule ChK-1 inhibitors. Compound $\mathbf{6 5}$ has emerged as a potent and selective compound with $\mathrm{IC}_{50}$ value $0.32 \mathrm{nM}$ [120].

Neff et al. have celebrated a new series of 2,5-disubstituted benzimidazole compounds containing pendant alcohol and amine moieties were found to be active against Chk2. Compound $\mathbf{6 6}$ was found to have the best inhibitory activity with $\mathrm{IC}_{50}$ value $14 \pm 8 \mathrm{nM}$ [121].

Galal et al. have applied a structure-based design to synthesize a new series of 2,5-di substituted benzimidazoles as a highly active and selective class of Chk2. The activities of the conjugates as checkpoint kinase inhibitors and as an antitumor were evaluated. The results indicated that compounds 67 and 68 inhibited Chk2 activity with high potency $\mathrm{IC}_{50}$ ranges from 5.5 to 52.8 nM [122].

A series of compounds comprising 2,5-disubstituted benzimidazole and dimethylpyrazolyl were synthesized. The cytotoxic activity of all compounds was tested against 60 types of human cancer cell lines. The results declared that compound 69 was found to be the most potent molecule against lung and breast cancers [123].
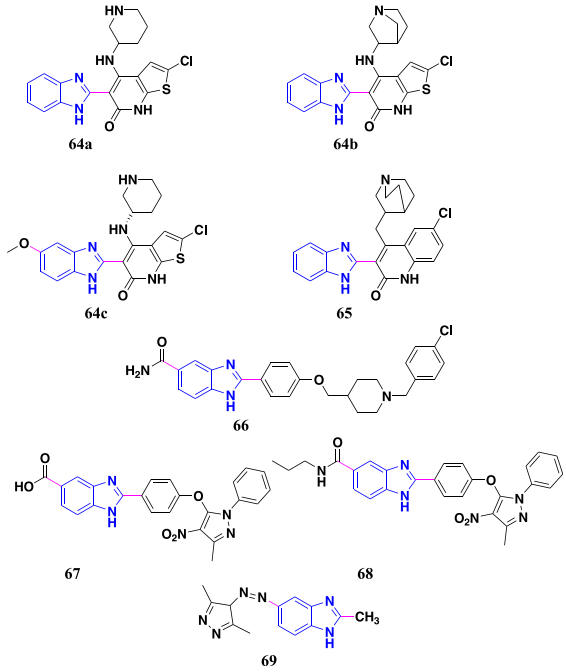

2-Substituted benzimidazoles as protein kinase rhCK2a inhibitors

Protein kinase 2 (CK2) is a constitutively active serine/ threonine protein kinase which takes part in a direction of substantial varieties of processes identified with cell survival and multiplication including cell cycle, apoptosis, or angiogenesis [124]. CK2 is a generally appropriated enzyme that phosphorylates various regulatory proteins [125]. CK2 articulation appears to be overexpressed in numerous solid tumors; consequently, inhibition of CK2 activity can reduce the viability of cancer cells [126].

Schneider et al. described the synthesis and CK2 inhibitory activity of 2-substituted-4,5,6,7-tetra halogenated benzimidazole derivatives. It was observed that, compound $\mathbf{7 0}$ displayed the highest activity towards CK2 with a half maximal lethal dose $\left(\mathrm{LD}_{50}\right)$ of $4.75 \pm$ $1.02 \mu \mathrm{M}$ [127].

Pagano et al. designed and synthesized conjugates of 2 -substituted tetrabromo-benzimidazole derivatives and examined against CK2 enzyme activity. Upon evaluation, compound 71 was shown to display the lowest $K_{\mathrm{i}}$ value as a CK2 inhibitor (40 $\mathrm{nM}$ ) [128].

In the same context, Andrzejewska et al. prepared 2substituted polyhalogenobenzimidazoles and assessed the combined derivatives for their CK2 inhibitory activity utilizing CK2 pure from rodent liver cytosol. The most effective hindrance of CK2 was achieved just if the benzene ring of benzimidazole is tetrahalogenated which is obviously confirmed by the $K_{\mathrm{i}}$ value of 4,5,6,7-tetrabromo-2-trifluoromethyl benzimidazole, $72 \quad\left(K_{\mathrm{i}}=\right.$ $0.60 \mu \mathrm{M})$ [129].

In addition, 1,2-disubstituted-1-H-benzimidazole was developed by Chojnacka et al. and assessed for protein kinase rhCK $2 \alpha$ catalytic subunit inhibition and 
cytotoxicity against two cancer cell lines. Compound 73 was identified as the most active with a $K_{\mathrm{i}}$ value $2.42 \pm$ $0.32 \mu \mathrm{M}[130]$.

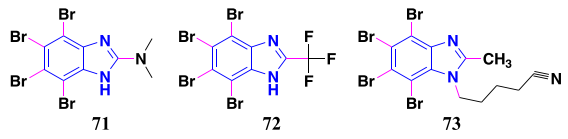

2-Substituted benzimidazoles as cyclin-dependant kinase inhibitors

Cyclin-dependent kinases (CDKs) constitute a class of serine-threonine protein kinases that play an important role in the regulation of the cell cycle [131].

Lin et al. reported the CDK inhibitory activity of a novel series of 2,4-disubstituted benzimidazolylpyrazolo[3,4-b]pyridines. The representative analog 74 was found to be a potent inhibitor of CDK1 with $\mathrm{IC}_{50}$ $0.0056 \mu \mathrm{M}$ and a significant decline of the in vitro cellular proliferation in HeLa, HCT116, and A375 human tumor cell lines with $\mathrm{IC}_{50} 0.015,0.010$, and $0.010 \mu \mathrm{M}$, respectively [132].

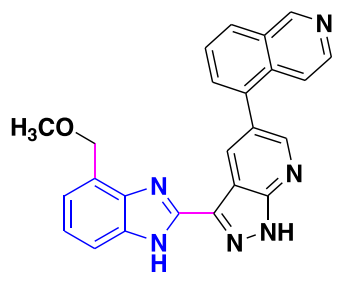

74

2-Substituted benzimidazoles as insulin-like growth factor receptor-1 inhibitors

The insulin-like growth factor receptor-1 (IGF-1R) is a membrane receptor tyrosine kinase. It plays an important role in mutagenesis and cell survival [133, 134]. Overexpression of IGF-1R and IGF-1 was demonstrated in a variety of tumors, including glioma, lung, ovary, breast, carcinomas, sarcomas, and melanoma [135].

Consequently, 2,5,7-trisubstituted benzimidazole (BMS-53692470) 75 was discovered as a novel small inhibitor of IGF-1R IC $50100 \mathrm{nM}$ [136].

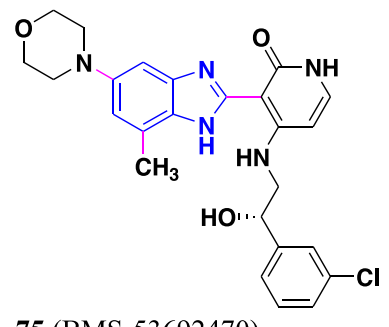

75 (BMS-53692470)

\section{2-Substituted benzimidazoles as allosteric mitogen-} activated protein kinase (MEK1) and phosphatidylinositol 3-kinase (PI3K) inhibitors

The phosphoinositide 3-kinase (PI3K) pathway is a key signal transduction system that links oncogenes and multiple receptor classes to many essential cellular functions and is perhaps the most commonly activated signaling pathway in human cancer. There are four highly homologous isoforms, assigned $\mathrm{PI} 3 \mathrm{~K} \alpha$, PI3K $\beta$, PI3K $\gamma$, and PI3K $\delta$, each having an unmistakable cluster of physiological capacities [137]. Initiating changes in PI3K $\alpha$ have been found in about a fourth of breast and endometrial tumors, recognizing PI3K as an imperative focus for novel growth therapeutics [138].

Recently, Dort et al. synthesized 1,2-disubstituted benzimidazole derivatives and displayed them as dual MEK/PI3K inhibitory agents by direct coupling of a potent PI3K inhibitor to an allosteric MEK inhibitor using a covalent linker moiety. A prototype dual-acting agent, compound $\mathbf{7 6}$ exhibited high in vitro inhibition of both PI3K $\left(\mathrm{IC}_{50}=172 \mathrm{nM}\right)$ and MEK1 $\left(\mathrm{IC}_{50}=473 \mathrm{nM}\right)[139]^{\text {. }}$

A new series of 1,2-disubstituted benzimidazole pyrimidone derivatives were blended by Certal et al. and assessed them for treatment of phosphatase and TENsin homolog (PTEN)-deficient cancers as PI3K $\beta$ has emerged as the isoform involved in the tumorigenicity of PTEN-deficient tumors. Among all compounds, 77, showed significant activity and selectivity for PI3K $\beta$ $\left(\mathrm{IC}_{50} 100 \mathrm{nM}\right)$, achieved tumor growth delay with $\mathrm{IC}_{50}$ ranging from 76 to $188 \mathrm{nM}$ and adequate in vitro pharmacokinetic properties. The SAR study showed that Nmethyl benzimidazole compound resulted in a slight improvement of activity, compared with 5-fluoro derivatives [140].

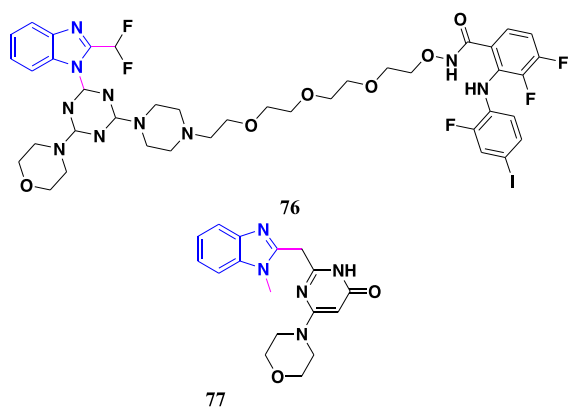

\section{2-Substituted benzimidazoles as a farnesyl-binding pocket of PDE $\delta$ inhibitors}

$\mathrm{K}$-Ras is one of the most common mutated signaltransducing human oncogenes. Ras signaling activity requires correct cellular localization of the GTPase. The spatial association of K-Ras is controlled by the prenylbinding protein PDE $\delta$ that has a fundamental part in keeping up with the best possible cell dispersion of Ras proteins. Thus inhibition of the Ras-PDE $\delta$ cooperation by small molecules hinders Ras signaling [141].

Zimmermann et al. described the design of a novel 1, 2-disubstituted benzimidazole derivatives as potent PDE $\delta$ supressors. Among the compounds developed, 
Table 1 Correlation between the type of substitution and the exerted mechanism of action

\begin{tabular}{|c|c|c|}
\hline Type of substitution & Mechanism of action & References \\
\hline $\begin{array}{l}\text { 1- } \mathrm{CH}_{3} \\
\text { 2-Aliphatic acid derivative } \\
\text { 5- Nitrogen mustard }\end{array}$ & Alkylating agent & {$[31,32]$} \\
\hline $\begin{array}{l}\text { 1,2-fused } \\
\text { 5-Amide } \\
\text { 6- } \mathrm{CH}_{3}\end{array}$ & Alkylating agent & [33] \\
\hline 2-Acridine & DNA binding agent & [34] \\
\hline $\begin{array}{l}\text { 2-Aromatic } \\
\text { 6-Oxindole }\end{array}$ & DNA binding agent & [35] \\
\hline $\begin{array}{l}\text { Head to tail bisbenzimidazole } \\
\text { 5-Aromatic/piperazine }\end{array}$ & DNA binding agent & [36] \\
\hline $\begin{array}{l}\text { 1-Aromatic } \\
\text { 2-Aromatic } \\
\text { 5-Ester }\end{array}$ & DNA binding agent & [37] \\
\hline 1,2-Fused & DNA binding agent & {$[38-40]$} \\
\hline $\begin{array}{l}\text { Cu complex with } \\
\text { tetrabenzimidazoles }\end{array}$ & DNA binding agent & [41] \\
\hline $\begin{array}{l}\text { 2-Indole } \\
\text { 4-Aromatic }\end{array}$ & Tubulin inhibitor & [45] \\
\hline $\begin{array}{l}\text { 2-Pyrazole } \\
\text { 6-Aliphatic/halogen }\end{array}$ & Tubulin inhibitor & [46] \\
\hline $\begin{array}{l}\text { 2-Carbamate } \\
\text { 5-Se connector/indole }\end{array}$ & Tubulin inhibitor & [47] \\
\hline $\begin{array}{l}\text { 2-Urea } \\
\text { 5-O-linker-Aromatic }\end{array}$ & Tubulin inhibitor & [48] \\
\hline $\begin{array}{l}\text { 2-Aromatic } \\
4-\mathrm{H} / \mathrm{OH} / \mathrm{CH}_{3}\end{array}$ & Tubulin inhibitor & [49] \\
\hline $\begin{array}{l}\text { 1-Aromatic ketone } \\
\text { 2-Aromatic }\end{array}$ & Tubulin inhibitor & {$[50]$} \\
\hline $\begin{array}{l}\text { 1,2-Aromatic } \\
5 \text {-Ester }\end{array}$ & Sirtuin $1 \& 2$ inhibitor & {$[56]$} \\
\hline $\begin{array}{l}\text { 2-Piperidine } \\
\text { 4-Carboxamide }\end{array}$ & Poly (ADP-ribose) polymerase inhibitor & [58] \\
\hline $\begin{array}{l}\text { 2-Aromatic } \\
\text { 4- Carboxamide } \\
\text { 5/6-Halogen }\end{array}$ & Poly (ADP-ribose) polymerase inhibitor & {$[59,60]$} \\
\hline $\begin{array}{l}\text { 2-Aromatic } \\
\text { 3,4-Fused }\end{array}$ & Poly (ADP-ribose) polymerase inhibitor & [61] \\
\hline $\begin{array}{l}2-\mathrm{CH}_{2}-\mathrm{OH} \\
5-\mathrm{NO}_{2}\end{array}$ & Methionine synthase inhibitors & [63] \\
\hline $\begin{array}{l}\text { 2-Aromatic amide } \\
\text { 5- } \mathrm{NO}_{2}\end{array}$ & Methionine synthase inhibitors & [64] \\
\hline $\begin{array}{l}\text { 1-Aromatic } \\
\text { 2- } \mathrm{CH}_{3} \\
\text { 6-Triazine }\end{array}$ & DHFR inhibitor & [67] \\
\hline $\begin{array}{l}\text { 1-Aromatic } \\
\text { 2- } \mathrm{CH}_{3} \\
\text { 6-Hetero-aromatic }\end{array}$ & DHFR inhibitor & [68] \\
\hline 2-Aromatic & Topoisomerase I\&ll inhibitors & {$[71,72]$} \\
\hline $\begin{array}{l}\text { 2-Aromatic } \\
\text { 4-Ester }\end{array}$ & Topoisomerase I\&l| inhibitors & [73] \\
\hline Head to tail bisbenzimidazole & Topoisomerase I\&ll inhibitors & {$[74,75]$} \\
\hline
\end{tabular}


Table 1 Correlation between the type of substitution and the exerted mechanism of action (Continued)

\begin{tabular}{|c|c|c|}
\hline Type of substitution & Mechanism of action & References \\
\hline $\begin{array}{l}\text { Cu comlex } \\
\text { 2-Pyridine } \\
\text { 5-COOH }\end{array}$ & Topoisomerase I\&ll inhibitors & [76] \\
\hline $\begin{array}{l}\text { 1-Aromatic } \\
\text { 2-C=O } \\
\text { 3-Aliphatic } \\
\text { 5- } \mathrm{NO}_{2}\end{array}$ & Androgen receptor antagonistic activity & [78] \\
\hline $\begin{array}{l}\text { 1-Aromatic } \\
\text { 2-Aliphatic } \\
5,6 \text {-Halogen }\end{array}$ & Androgen receptor antagonistic activity & [79] \\
\hline $\begin{array}{l}\text { 2-Aromatic } \\
\text { 5,6-Aliphatic }\end{array}$ & a-glucosidase inhibitors & [82] \\
\hline $\begin{array}{l}\text { 1,2-Aromatic } \\
\text { 5-Amide }\end{array}$ & G9a Histone Methyltransferase inhibitors & [85] \\
\hline $\begin{array}{l}\text { 1-Hetero-aromatic } \\
\text { 2-Aromatic }\end{array}$ & Pyruvate kinase inhibitors & [88] \\
\hline $\begin{array}{l}\text { Head to Head bisbenzimidazoles } \\
\text { 2-Hetero-aromatic connector } \\
\text { 6-Piperazine }\end{array}$ & Telomerazse inhibitors & [89] \\
\hline $\begin{array}{l}\text { Tribenzimidazoles } \\
\text { 2-Aromatic } \\
\text { 6-Piperazine }\end{array}$ & Telomerazse inhibitors & [90] \\
\hline $\begin{array}{l}\text { 5,6-Fused } \\
\text { 2-Cyclic amine/piperazine }\end{array}$ & Telomerazse inhibitors & [91] \\
\hline 2-Aromatic & VEGFR-2 inhibitor & [98] \\
\hline $\begin{array}{l}\text { 2-Aromatic } \\
\text { 6-Quinoline }\end{array}$ & VEGFR-2 inhibitor & [92] \\
\hline $\begin{array}{l}\text { 1-Aromatic } \\
\text { 2-Furan }\end{array}$ & VEGFR-2 inhibitor & [99] \\
\hline $\begin{array}{l}\text { 1-Amide/Heteroaromatic } \\
\text { 2-Furan }\end{array}$ & VEGFR-2 inhibitor & {$[100]$} \\
\hline $\begin{array}{l}\text { 2-Amide } \\
\text { 5,6-Aliphatic }\end{array}$ & VEGFR-2 inhibitor & [101] \\
\hline 2-Oxadiazole & EGFR inhibitors & [107] \\
\hline $\begin{array}{l}\text { 1-Aliphatic amine } \\
\text { 2-Amide } \\
\text { 6-Halogen }\end{array}$ & EGFR inhibitors & [108] \\
\hline $\begin{array}{l}\text { 2-Indazole } \\
\text { 5-Piperazine }\end{array}$ & FGFR1 inhibitors & [110] \\
\hline $\begin{array}{l}\text { 2-Aromatic ketone } \\
\text { 6-Aliphatic }\end{array}$ & FGFR1 inhibitors & [111] \\
\hline $\begin{array}{l}\text { 2-Pyrrolopyrimidine } \\
\text { 5-Sulfonyl/urea }\end{array}$ & Tie-2 receptor tyrosine kinase inhibitors & [95] \\
\hline $\begin{array}{l}\text { 2-Aromatic } \\
\text { 5, 6-Aliphatic }\end{array}$ & Heparanase inhibitors & [114] \\
\hline 2-Aromatic & COX1\&2 inhibitors & [117] \\
\hline $\begin{array}{l}\text { 2-Pyrazole } \\
\text { 5-Aliphatic amine }\end{array}$ & Aurora A/B kinase inhibitors & {$[120]$} \\
\hline $\begin{array}{l}\text { 2-NH-aromatic } \\
5-\mathrm{CF}_{3}\end{array}$ & Aurora A/B kinase inhibitors & [121] \\
\hline $\begin{array}{l}\text { 2-Pyrazole } \\
\text { 5-Morpholine }\end{array}$ & Aurora A/B kinase inhibitors & {$[122]$} \\
\hline $\begin{array}{l}\text { 1,2-Aliphatic } \\
\text { 5-Hetero-aromatic }\end{array}$ & Aurora A/B kinase inhibitors & [123] \\
\hline
\end{tabular}


Table 1 Correlation between the type of substitution and the exerted mechanism of action (Continued)

\begin{tabular}{|c|c|c|}
\hline Type of substitution & Mechanism of action & References \\
\hline 2-Hetero-aromatic & Checkpoint kinase (Chk1\&Chk2) inhibitors & [127] \\
\hline 2-Hetero-aromatic & Checkpoint kinase (Chk1\&Chk2) inhibitors & [128] \\
\hline $\begin{array}{l}\text { 2-Aromatic } \\
\text { 5-Amide }\end{array}$ & Checkpoint kinase (Chk1\&Chk2) inhibitors & [129] \\
\hline $\begin{array}{l}\text { 2-Aromatic } \\
\text { 5-COOH/Amide }\end{array}$ & Checkpoint kinase (Chk1\&Chk2) inhibitors & [130] \\
\hline $\begin{array}{l}2-\mathrm{CH}_{3} \\
5 \text {-Pyrazole }\end{array}$ & Checkpoint kinase (Chk1\&Chk2) inhibitors & [131] \\
\hline $\begin{array}{l}\text { 2-Aliphatic amines } / \mathrm{CF}_{3} \\
\text { 4,5,6,7-Halogen }\end{array}$ & Protein kinase rhCK2a inhibitor & {$[135,136]$} \\
\hline $\begin{array}{l}2-\mathrm{CF}_{3} \\
4,5,6,7-\text { Halogen }\end{array}$ & Protein kinase rhCK2a inhibitor & [137] \\
\hline $\begin{array}{l}\text { 2- } \mathrm{CH}_{3} \\
4,5,6,7-\text { Halogen }\end{array}$ & Protein kinase rhCK2a inhibitor & [138] \\
\hline $\begin{array}{l}\text { 2-Pyrazolo-pyridine } \\
\text { 4-Aliphatic }\end{array}$ & Cyclin-dependant kinase (CDK) inhibitors & [140] \\
\hline $\begin{array}{l}\text { 2-Hetero-aromatic } \\
\text { 4-Morpholine } \\
\text { 7-Aliphatic }\end{array}$ & Insulin-like growth factor receptor-1 (IFG-1R) inhibitors & [144] \\
\hline $\begin{array}{l}\text { 1-Triazine } \\
\text { 2-Halogen }\end{array}$ & $\begin{array}{l}\text { Allosteric Mitogen-Activated Protein Kinase (MEK1) and Phosphatidylinositol 3-Kinase (PI3K) } \\
\text { inhibitors }\end{array}$ & [147] \\
\hline 2-Hetero-aromatic & $\begin{array}{l}\text { allosteric Mitogen-Activated Protein Kinase (MEK1) and Phosphatidylinositol 3-Kinase (PI3K) } \\
\text { inhibitors }\end{array}$ & [148] \\
\hline 1,2-Aromatic & Farnesyl binding pocket of PDE $\delta$ inhibitor & [141] \\
\hline $\begin{array}{l}\text { 1-Triazine } \\
\text { 2-CHF2 } \\
\text { 3-O-linker }\end{array}$ & Farnesyl binding pocket of PDE $\delta$ inhibitor & [143] \\
\hline $\begin{array}{l}\text { 2-Aromatic } \\
\text { 6-Quinazolin }\end{array}$ & Dual c-Met and VEGFR-2 inhibitors & [145] \\
\hline $\begin{array}{l}\text { 2-Hetero-aromatic } \\
\text { 6-Piperazine }\end{array}$ & Multi-target receptor tyrosine kinase inhibitors & [147] \\
\hline $\begin{array}{l}\text { 2-Pyrole } \\
\text { 6-Amide }\end{array}$ & Multi-target receptor tyrosine kinase inhibitors & [148] \\
\hline $\begin{array}{l}\text { 2-Pyrazine } \\
\text { 6-Aliphatic amine }\end{array}$ & Multi-target receptor tyrosine kinase inhibitors & [149] \\
\hline $\begin{array}{l}\text { 1-Aliphatic } \\
\text { 2-Aromatic amine }\end{array}$ & Multi-target receptor tyrosine kinase inhibitors & [149] \\
\hline
\end{tabular}

compound 78 was reported as the most active compound of the series against the farnesyl-binding pocket of PDE $\delta$ with KD $87 \pm 35$ nanomolar affinity as the introduction of a piperidine moiety acts as a hydrogenbonding donor [142].

A series of 4-substituted derivatives of the pan class I PI 3-kinase inhibitor 2-(difluoromethyl)-1-[4,6-di-(4morpholinyl)-1,3,5-triazin-2-yl]-1H-benzimidazole (ZSTK474) were prepared by Rewcastle et al. to synthesize a range of 1,2,4-trisubstituted benzimidazole derivatives with 4-aminoalkoxy substituents. The compounds were evaluated using two human tumor cell lines. Upon evaluation, it was found that compound $\mathbf{7 9}$ displayed the best enzyme inhibitor with $\mathrm{IC}_{50}$ ranges from 4.5 to $11 \mu \mathrm{M}$ and revealed the highest antitumor activity with $\mathrm{IC}_{50} 0.04 \mu \mathrm{M}$. Moreover, 79 showed the best overall activity against the U87MG xenograft model, but less potent than ZSTK474 [143].
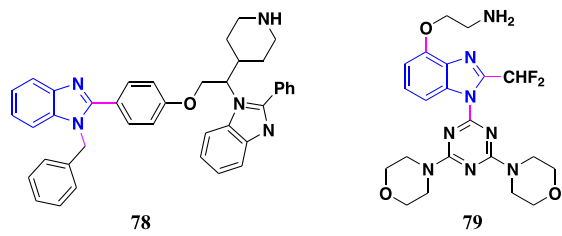

79

\section{2-Substituted benzimidazoles as dual c-Met and VEGFR-2 inhibitors}

c-Met (mesenchymal endothelial transition) kinase is a subclass that is important, associated with its ligand, hepatocyte growth factor (HGF), for normal mammalian 
growth [144]. Targeting several biochemical paths of cancer can be accomplished by using several drugs with different modes of action or through a single moiety that could adjust multiple targets of a multi-component disorder [145].

Accordingly, 2,6-disubstituted benzoimidazolyl quinazolinamine derivatives were synthesized and evaluated by Shi et al. Compound $\mathbf{8 0}$ was found to be the most potent against c-Met and VEGFR-2 with of $\mathrm{IC}_{50}$ of 0.05 $\mu \mathrm{M}$ and $0.02 \mu \mathrm{M}$ respectively [146].<smiles>Fc1ccc(-c2nc3ccc(Nc4ncnc5ccccc45)cc3[nH]2)cc1</smiles>

80

\section{2-Substituted benzimidazoles as multi-target receptor tyrosine kinase inhibitors}

The development of resistance against drugs that act as a single kinase inhibitor makes inhibition of more than one protein kinase an acceptable idea because tumor cells are attacked concomitantly at several relevant targets. Moreover, if a single cancer-related kinase becomes drug-resistant, a multi-targeted drug would still act on the remaining array of target kinases. Some benzimidazoles with 2,6-disubstitution were found to have multi-target receptor tyrosine kinase inhibitory activity. Dovitinib, 81, a substituted 3benzimidazol hydroquinolin-2-one, exhibited dual inhibition of FGFR (fibroblast growth factor receptor) and VEFGRs [147].

Li et al. designed a new series of 2,6-disubstituted benzimidazoles and evaluated their biological activity against HEPG-2 cells and different kinases (EGFR, PDGFR-a, PDGFR-b, VEGFR-2). Compound $\mathbf{8 2}$ was found to exhibit high cytotoxicity against HEPG-2 cells with an $\mathrm{IC}_{50}$ value of approximately $2 \mu \mathrm{M}$. Further kinase assay study showed that $\mathbf{8 2}$ has $\mathrm{IC}_{50} 86.9,18.7$, and $16.5 \mu \mathrm{M}$ against EGFR, VEFGR-2, and PDGFR, respectively [148].

McBride et al. synthesized 2,5-disubstituted benzimidazole indazole hybrids as multi-inhibitors of VEGFR-1, VEGFR-2, PDGFR, FGFR-1, and HUVEC and found that compounds 83 possessed favorable pharmacokinetics and exhibit impressive tumor growth inhibition property against different cell lines tested with $\mathrm{IC}_{50} 0.028,0.078,0.69,0.048$, and $0.097 \mu \mathrm{M}$, respectively [149].

Determann et al. reported the synthesis of 1,2-disubstituted benzimidazole derivatives and evaluated against four cancer-related protein kinases namely Aurora B, PLK1 (polo-like kinase 1), FAK (focal adhesion kinase), and VEFGR-2, where compound $\mathbf{8 4}$ demonstrated high inhibitory activity with $\mathrm{IC}_{50}$ values $6.0 \pm 0.2,1.2 \pm 0.2$, $3.4 \pm 0.8,7.2 \pm 0.3 \mu \mathrm{M}$, respectively [98].
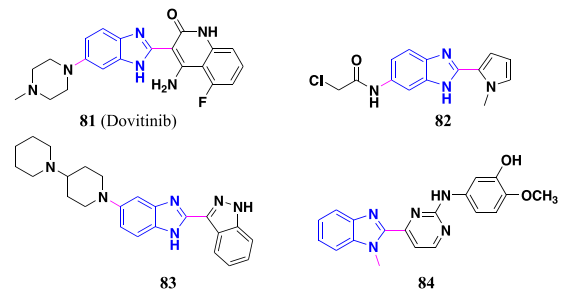

\section{Conclusion}

This review highlights the current status of 2-substituted benzimidazole anticancer molecules. The linker group and substitution at $\mathrm{N}-1, \mathrm{C}-2, \mathrm{C}-5$, and $\mathrm{C}-6$ positions have been found to be the most contributory factors for anticancer activity. Table 1 of SM is a correlation between the type of substitution and the exerted mechanism of action. We hope this paper will form a comprehensive foundation and reference source that will open up new opportunities for researchers interested in drug designing of benzimidazoles as anticancer. This depends on the specific design of molecules targeting multiple receptors/enzyme/protein, particularly keeping in mind to lessen side effects and toxicity.

\section{Abbreviations}

$\mathrm{G}$ : Guanine; A: Adenosine; $\mathrm{IC}_{50}$ : Half maximal inhibitory concentration; SAR: Structure-activity relationship; CDK2: Cyclin-dependent kinase-2; PCNA: Proliferation cell nuclear antigen; NCl: National Cancer Institute; NSCL C: Non-small-cell lung cancer; $\mathrm{Gl}_{50}$ : Half maximal inhibitory growth; Ki: Inhibitory constant and reflective of the binding affinity; PF $_{50}$ : Potentiation effect; HDAC: Histone deacetylases; PARP-1: Poly (ADP-ribose) polymerase-1; MetS: Methionine synthase; DHFR: Dihydrofolate reductase; ct-

DNA: Circulating tumor DNA; ID 50 : Half maximal inhibitory dose; HMTs: Histone methyltransferase; PKM2: M2 isoform of pyruvate kinase; hTERT: Human telomerase reverse transcriptase; VEGF: Vascular endothelial growth factor; RTK: Receptor tyrosine kinase; VEGFR: Vascular endothelial growth factor receptor; HUVEC: Human umbilical vein endothelial cell; KDR: Kinase domain receptor; EGFR: Epidermal growth factor receptor; FGFRs: Fibroblast growth factor receptors; TGI: Tumor growth inhibition; COX: Cyclooxygenase; S.I.: Selective inhibition; Chk: Checkpoint kinase; PK: Protein kinase; CDK: Cyclin-dependent kinase; PI3K: Phosphoinositide 3kinase; MEK: Mitogen-activated protein kinase; PDES: Prenyl-binding protein; c-Met: Cytoplasmic mesenchymal endothelial transition; PDGFR: Plateletderived growth factor receptor; Gl: Growth inhibition; EC $_{50}$ : Median effective concentration required to induce a 50\% effect

\section{Plagiarism declaration}

I hereby declare that this submission is my own work and to best of my knowledge, it contains no material previously published or written by another person, except where due acknowledgement is made. Furthermore, I believe that no contents of this material have been accepted for the award of any other degree or diploma in any other university or tertiary institution.

\section{Authors' contributions}

HA: data collection and integration, prepared the first draft of the manuscript. HM: supervision and manuscript preparation. All authors have read and approved the manuscript.

Funding

Not applicable.

Availability of data and materials Not applicable. 


\section{Ethics approval and consent to participate}

Not applicable.

\section{Consent for publication}

Not applicable.

\section{Competing interests}

The authors declare that they have no competing interests.

Received: 18 October 2019 Accepted: 29 January 2020

Published online: 29 July 2020

\section{References}

1. Nepali K, Sharma S, Sharma M, Bedi P, Dhar K (2014) Rational approaches, design strategies, structure activity relationship and mechanistic insights for anticancer hybrids. European Journal of Medicinal Chemistry 77:422-487

2. Fadeyi OO, Adamson ST, Myles EL, Okoro CO (2008) Novel fluorinated acridone derivatives. Part 1: Synthesis and evaluation as potential anticancer agents. Bioorganic \& Medicinal Chemistry Letters 18(14):4172-4176

3. Rostom SA (2006) Synthesis and in vitro antitumor evaluation of some indeno [1, 2-c] pyrazol (in) es substituted with sulfonamide, sulfonylurea (-thiourea) pharmacophores, and some derived thiazole ring systems. Bioorganic \& Medicinal Chemistry 14(19):6475-6485

4. Bajaj S, Asati V, Singh J, Roy PP (2015) 1, 3, 4-Oxadiazoles: an emerging scaffold to target growth factors, enzymes and kinases as anticancer agents. European Journal of Medicinal Chemistry 97:124-141

5. Ferlay J, Soerjomataram I, Dikshit R, Eser S, Mathers C, Rebelo M et al (2015) Cancer incidence and mortality worldwide: sources, methods and major patterns in GLOBOCAN 2012. International Journal of Cancer 136(5):E359E386

6. Husain A, Rashid M, Mishra R, Parveen S, Shin D-S, Kumar D (2012) Benzimidazole bearing oxadiazole and triazolo-thiadiazoles nucleus: design and synthesis as anticancer agents. Bioorganic \& Medicinal Chemistry Letters 22(17):5438-5444

7. Kidwai M, Venktaramanan R, Mohan R, Sapra P (2002) Cancer chemotherapy and heterocyclic compounds. Current Medicinal Chemistry 9(12):1209-1228

8. Lee CW, Hong DH, Han SB, Jung S-H, Kim HC, Fine RL et al (2002) A novel stereo-selective sulfonylurea, 1-[1-(4-aminobenzoyl)-2, 3-dihydro-1H-indol-6sulfonyl]-4-phenyl-imidazolidin-2-one, has antitumor efficacy in in vitro and in vivo tumor models. Biochemical Pharmacology 64(3):473-480

9. Gaba M, Singh S, Mohan C (2014) Benzimidazole: an emerging scaffold for analgesic and anti-inflammatory agents. European Journal of Medicinal Chemistry 76:494-505

10. Toohey J, Barker H (1961) Isolation of coenzyme B12 from liver. Journal of Biological Chemistry 236(2):560-563

11. Akhtar J, Khan AA, Ali Z, Haider R, Shahar Yar M (2017) Structure-activity relationship (SAR) study and design strategies of nitrogen-containing heterocyclic moieties for their anticancer activities. European Journal of Medicinal Chemistry 125:143-189

12. Carcanague D, Shue Y-K, Wuonola MA, Uria-Nickelsen M, Joubran C, Abedi JK et al (2002) Novel Structures Derived from 2-[[(2-Pyridyl) methyl] thio]-1 $\mathrm{H}$-benzimidazole as Anti-Helicobacter p ylori Agents, Part 2. Journal of Medicinal Chemistry 45(19):4300-4309

13. Aghatabay NM, Somer M, Senel M, Dulger B, Gucin F (2007) Raman, FT-IR, NMR spectroscopic data and antimicrobial activity of bis [ $\mu$ 2-(benzimidazol2-yl)-2-ethanethiolato-N, S, S-chloro-palladium (II)] dimer, $[(\mu \mathrm{2}-\mathrm{CH} 2 \mathrm{CH} 2$ NHNCC $6 \mathrm{H}$ 4) PdCl] 2. $\mathrm{C} 2 \mathrm{H} 5 \mathrm{OH}$ complex. European Journal of Medicinal Chemistry 42(8):1069-1075

14. Demirayak S, Karaburun AC, Kayagil I, Uçucu U, Beis R (2005) Synthesis and Analgesic Activities of Some 2-(Benzazolylacetyl) amino-3ethoxycarbonylthiophene Derivatives. Phosphorus, Sulfur, and Silicon and the Related Elements 180(8):1841-1848

15. Locatelli A, Cosconati S, Micucci M, Leoni A, Marinelli L, Bedini A et al (2013) Ligand based approach to L-type calcium channel by imidazo [2, 1-b] thiazole-1, 4-dihydropyridines: from heart activity to brain affinity. Journal of Medicinal Chemistry 56(10):3866-3877

16. Yadav G, Ganguly S (2015) Structure activity relationship (SAR) study of benzimidazole scaffold for different biological activities: a mini-review. European Journal of Medicinal Chemistry 97:419-443
17. Gaba M, Gaba P, Uppal D, Dhingra N, Bahia MS, Silakari O et al (2015) Benzimidazole derivatives: search for Gl-friendly anti-inflammatory analgesic agents. Acta Pharmaceutica Sinica B 5(4):337-342

18. Gaba M, Mohan C (2016) Development of drugs based on imidazole and benzimidazole bioactive heterocycles: recent advances and future directions. Medicinal Chemistry Research 25(2):173-210

19. Hobrecker F (1872) Reduction-products of nitracetamide compounds. Deut Chem Ges Ber 5:920-924

20. Ladenburg A (1879) Ueber einige Derivate der Tropasäure. Berichte der deutschen chemischen Gesellschaft 12(1):947-948

21. Wright JB (1951) The chemistry of the benzimidazoles. Chemical Reviews 48(3):397-541

22. Alaqeel SI (2017) Synthetic approaches to benzimidazoles from ophenylenediamine: a literature review. Journal of Saudi Chemical Society 21(2):229-237

23. Zhu J, Zhang Z, Miao C, Liu W, Sun W (2017) Synthesis of benzimidazoles from o-phenylenediamines and DMF derivatives in the presence of $\mathrm{PhSiH} 3$. Tetrahedron 73(25):3458-3462

24. Shrivastava N, Naim M, Alam M, Nawaz F, Ahmed S, Alam O (2017) Benzimidazole Scaffold as anticancer agent: synthetic approaches and structure-activity relationship. Archiv der Pharmazie.

25. Sawyers C (2004) Targeted cancer therapy. Nature 432(7015):294-297

26. Gerber DE (2008) Targeted therapies: a new generation of cancer treatments. American Family Physician 77(3):311-319

27. Lissitchkov T, Arnaudov G, Peytchev D, Merkle K (2006) Phase-I/II study to evaluate dose limiting toxicity, maximum tolerated dose, and tolerability of bendamustine $\mathrm{HCl}$ in pre-treated patients with B-chronic lymphocytic leukaemia (Binet stages B and C) requiring therapy. Journal of Cancer Research and Clinical Oncology 132(2):99-104

28. Husain A, Rashid M, Shaharyar M, Siddiqui AA, Mishra R (2013) Benzimidazole clubbed with triazolo-thiadiazoles and triazolo-thiadiazines: new anticancer agents. European Journal of Medicinal Chemistry 62:785-798

29. Schulz WG, Islam I, Skibo EB (1995) Pyrrolo [1, 2-a] benzimidazole-based quinones and iminoquinones. The role of the 3-substituent on cytotoxicity. Journal of Medicinal Chemistry 38(1):109-118

30. Gao C, Li B, Zhang B, Sun Q, Li L, Li X et al (2015) Synthesis and biological evaluation of benzimidazole acridine derivatives as potential DNA-binding and apoptosis-inducing agents. Bioorganic \& Medicinal Chemistry 23(8): 1800-1807

31. Nayak VL, Nagaseshadri B, Vishnuvardhan M, Kamal A (2016) Investigation of the apoptotic pathway induced by benzimidazole-oxindole conjugates against human breast cancer cells MCF-7. Bioorganic \& Medicinal Chemistry Letters 26(14):3313-3317

32. Chen AY, Yu C, Bodley A, Peng LF, Liu LF (1993) A new mammalian DNA topoisomerase I poison Hoechst 33342: cytotoxicity and drug resistance in human cell cultures. Cancer Research 53(6):1332-1337

33. Gowda NT, Kavitha C, Chiruvella KK, Joy O, Rangappa KS, Raghavan SC (2009) Synthesis and biological evaluation of novel 1-(4-methoxyphenethyl)$1 \mathrm{H}$-benzimidazole-5-carboxylic acid derivatives and their precursors as antileukemic agents. Bioorganic \& Medicinal Chemistry Letters 19(16):4594-4600

34. Hranjec M, Pavlović G, Marjanović M, Kralj M, Karminski-Zamola G (2010) Benzimidazole derivatives related to 2, 3-acrylonitriles, benzimidazo [1, 2-a] quinolines and fluorenes: synthesis, antitumor evaluation in vitro and crystal structure determination. European Journal of Medicinal Chemistry 45(6): 2405-2417

35. Neochoritis CG, Zarganes-Tzitzikas T, Tsoleridis CA, StephanidouStephanatou J, Kontogiorgis CA, Hadjipavlou-Litina DJ et al (2011) One-pot microwave assisted synthesis under green chemistry conditions, antioxidant screening, and cytotoxicity assessments of benzimidazole Schiff bases and pyrimido [1, 2-a] benzimidazol-3 (4H)-ones. European Journal of Medicinal Chemistry 46(1):297-306

36. Demirayak S, Kayagil I, Yurttas L (2011) Microwave supported synthesis of some novel 1, 3-Diarylpyrazino [1, 2-a] benzimidazole derivatives and investigation of their anticancer activities. European Journal of Medicinal Chemistry 46(1):411-416

37. Zhou Q, Yang P (2006) Crystal structure and DNA-binding studies of a new Cu (II) complex involving benzimidazole. Inorganica Chimica Acta 359(4): 1200-1206

38. Perez EA (2009) Microtubule inhibitors: differentiating tubulin-inhibiting agents based on mechanisms of action, clinical activity, and resistance. Molecular Cancer Therapeutics 8(8):2086-2095 
39. Harris F, Pierpoint L (2012) Photodynamic therapy based on 5aminolevulinic acid and its use as an antimicrobial agent. Medicinal Research Reviews 32(6):1292-1327

40. Jordan MA, Wilson $L$ (2004) Microtubules as a target for anticancer drugs. Nature Reviews Cancer 4(4):253-265

41. Lu Y, Chen J, Wang J, Li C-M, Ahn S, Barrett CM et al (2014) Design, synthesis, and biological evaluation of stable colchicine binding site tubulin inhibitors as potential anticancer agents. Journal of Medicinal Chemistry 57(17):7355-7366

42. Kamal A, Shaik AB, Polepalli S, Kumar GB, Reddy VS, Mahesh R et al (2015) Synthesis of arylpyrazole linked benzimidazole conjugates as potential microtubule disruptors. Bioorganic \& Medicinal Chemistry 23(5):1082-1095

43. Guan Q, Han C, Zuo D, Li Z, Zhang Q, Zhai Y et al (2014) Synthesis and evaluation of benzimidazole carbamates bearing indole moieties for antiproliferative and antitubulin activities. European Journal of Medicinal Chemistry 87:306-315

44. Wang W, Kong D, Cheng H, Tan L, Zhang Z, Zhuang X et al (2014) New benzimidazole-2-urea derivates as tubulin inhibitors. Bioorganic \& Medicinal Chemistry Letters 24(17):4250-4253

45. Kamal A, Reddy MK, Shaik TB, Srikanth Y, Reddy VS, Kumar GB et al (2012) Synthesis of terphenyl benzimidazoles as tubulin polymerization inhibitors. European Journal of Medicinal Chemistry 50:9-17

46. Wang Y-T, Qin Y-J, Yang N, Zhang Y-L, Liu C-H, Zhu H-L (2015) Synthesis, biological evaluation, and molecular docking studies of novel 1-benzene acyl-2-(1-methylindol-3-yl)-benzimidazole derivatives as potential tubulin polymerization inhibitors. European Journal of Medicinal Chemistry 99:125-137

47. Blander G, Guarente L (2004) The Sir2 family of protein deacetylases. Annual Review of Biochemistry 73(1):417-435

48. Sebastián C, Satterstrom FK, Haigis MC, Mostoslavsky R (2012) From sirtuin biology to human diseases: an update. Journal of Biological Chemistry 287(51):42444-42452

49. Frye RA (2000) Phylogenetic classification of prokaryotic and eukaryotic Sir2like proteins. Biochemical and Biophysical Research Communications 273(2): 793-798

50. Saunders L, Verdin E (2007) Sirtuins: critical regulators at the crossroads between cancer and aging. Oncogene 26(37):5489-5504

51. Zhao W, Kruse J-P, Tang Y, Jung SY, Qin J, Gu W (2008) Negative regulation of the deacetylase SIRT1 by DBC1. Nature 451(7178):587-590

52. Yoon YK, Ali MA, Wei AC, Shirazi AN, Parang K, Choon TS (2014) Benzimidazoles as new scaffold of sirtuin inhibitors: green synthesis, in vitro studies, molecular docking analysis and evaluation of their anti-cancer properties. European Journal of Medicinal Chemistry 83:448-454

53. Drew Y, Mulligan EA, Vong W-T, Thomas HD, Kahn S, Kyle S et al (2011) Therapeutic potential of poly (ADP-ribose) polymerase inhibitor AG014699 in human cancers with mutated or methylated BRCA1 or BRCA2. Journal of the National Cancer Institute 103(4):334-346

54. Penning TD, Zhu G-D, Gandhi VB, Gong J, Liu X, Shi Y et al (2008) Discovery of the poly (ADP-ribose) polymerase (PARP) inhibitor 2-[(R)-2methylpyrrolidin-2-yl]-1 H-benzimidazole-4-carboxamide (ABT-888) for the treatment of cancer. Journal of Medicinal Chemistry 52(2):514-523

55. Abdullah I, Chee CF, Lee Y-K, Thunuguntla SSR, Reddy KS, Nellore K et al (2015) Benzimidazole derivatives as potential dual inhibitors for PARP-1 and DHODH. Bioorganic \& Medicinal Chemistry 23(15):4669-4680

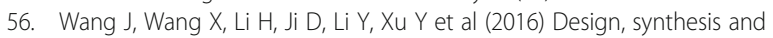
biological evaluation of novel 5-fluoro-1H-benzimidazole-4-carboxamide derivatives as potent PARP-1 inhibitors. Bioorganic \& Medicinal Chemistry Letters 26(16):4127-4132

57. Zhou D, Chu W, Xu J, Jones LA, Peng X, Li S et al (2014) Synthesis,[18 F] radiolabeling, and evaluation of poly (ADP-ribose) polymerase-1 (PARP-1) inhibitors for in vivo imaging of PARP-1 using positron emission tomography. Bioorganic \& Medicinal Chemistry 22(5):1700-1707

58. Zhou Z, Garrow TA, Dong X, Luchini DN, Loor JJ (2017) Hepatic activity and transcription of betaine-homocysteine methyltransferase, methionine synthase, and cystathionine synthase in periparturient dairy cows are altered to different extents by supply of methionine and choline. The Journal of Nutrition 147(1):11-19

59. Ahmed HA (2011) Molecular modeling and synthesis of certain substituted aryl compounds which have a potential anticancer activity. Bulletin of Faculty of Pharmacy, Cairo University 49(1):25-36

60. Elshihawy H, Helal MA, Said M, Hammad MA (2014) Design, synthesis, and enzyme kinetics of novel benzimidazole and quinoxaline derivatives as methionine synthase inhibitors. Bioorganic \& Medicinal Chemistry 22(1):550558

61. Singla P, Luxami V, Paul K (2015) Triazine-benzimidazole hybrids: anticancer activity, DNA interaction and dihydrofolate reductase inhibitors. Bioorganic \& Medicinal Chemistry 23(8):1691-1700

62. Singla P, Luxami V, Paul K (2017) Quinazolinone-benzimidazole conjugates: synthesis, characterization, dihydrofolate reductase inhibition, DNA and protein binding properties. Journal of Photochemistry and Photobiology B: Biology 168:156-164

63. Larsen AK, Escargueil AE, Skladanowski A (2003) Catalytic topoisomerase II inhibitors in cancer therapy. Pharmacology \& Therapeutics 99(2):167-181

64. Nitiss UL (2009) Targeting DNA topoisomerase II in cancer chemotherapy. Nature Reviews Cancer 9(5):338-350

65. Coban G, Zencir S, Zupkó I, Réthy B, Gunes HS, Topcu Z (2009) Synthesis and biological activity evaluation of $1 \mathrm{H}$-benzimidazoles via mammalian DNA topoisomerase I and cytostaticity assays. European Journal of Medicinal Chemistry 44(5):2280-2285

66. Singla P, Luxami V, Singh R, Tandon V, Paul K (2017) Novel pyrazolo [3, 4-d] pyrimidine with 4-(1H-benzimidazol-2-yl)-phenylamine as broad spectrum anticancer agents: Synthesis, cell based assay, topoisomerase inhibition, DNA intercalation and bovine serum albumin studies. European Journal of Medicinal Chemistry 126:24-35

67. Pinar A, Yurdakul P, Yildiz I, Temiz-Arpaci O, Acan NL, Aki-Sener E et al (2004) Some fused heterocyclic compounds as eukaryotic topoisomerase II inhibitors. Biochemical and Biophysical Research Communications 317(2): $670-674$

68. Singh M, Tandon V (2011) Synthesis and biological activity of novel inhibitors of topoisomerase I: 2-Aryl-substituted 2-bis-1H-benzimidazoles. European Journal of Medicinal Chemistry 46(2):659-669

69. Jin S, Kim J, Sim S, Liu A, Pilch D, Liu F et al (2000) Design and structureactivity relationship of 3-benzimidazol-2-yl-1H-indazoles as inhibitors of receptor tyrosine kinases. Bioorganic and Medicinal Chemistry Letters 10: 719-723

70. Galal SA, Hegab KH, Hashem AM, Youssef NS (2010) Synthesis and antitumor activity of novel benzimidazole-5-carboxylic acid derivatives and their transition metal complexes as topoisomerease II inhibitors. European Journal of Medicinal Chemistry 45(12):5685-5691

71. Kokontis JM, Liao S (1998) Molecular action of androgen in the normal and neoplastic prostate. Vitamins and Hormones 55:219-307

72. Elancheran R, Saravanan K, Choudhury B, Divakar S, Kabilan S, Ramanathan $M$ et al (2016) Design and development of oxobenzimidazoles as novel androgen receptor antagonists. Medicinal Chemistry Research 25(4):539-552

73. Ng RA, Guan J, Alford VC, Lanter JC, Allan GF, Sbriscia T et al (2007) 2-(2, 2 2-Trifluoroethyl)-5, 6-dichlorobenzimidazole derivatives as potent androgen receptor antagonists. Bioorganic \& Medicinal Chemistry Letters 17(4):955-958

74. Kimura A, Lee J-H, Lee I-S, Lee H-S, Park K-H, Chiba S et al (2004) Two potent competitive inhibitors discriminating a-glucosidase family I from family II. Carbohydrate Research 339(6):1035-1040

75. Zawawi NKNA, Taha M, Ahmat N, Ismail NH, Wadood A, Rahim F (2017) Synthesis, molecular docking studies of hybrid benzimidazole as aglucosidase inhibitor. Bioorganic Chemistry 70:184-191

76. Jenuwein T (2006) The epigenetic magic of histone lysine methylation. The FEBS journal 273(14):3121-3135

77. Albert M, Helin K, editors. Histone methyltransferases in cancer. Seminars in Cell \& Developmental Biology; 2010: Elsevier.

78. Zhang J, Yao D, Jiang Y, Huang J, Yang S, Wang J (2017) Synthesis and biological evaluation of benzimidazole derivatives as the G9a Histone Methyltransferase inhibitors that induce autophagy and apoptosis of breast cancer cells. Bioorganic Chemistry 72:168-181

79. Christofk HR, Vander Heiden MG, Harris MH, Ramanathan A, Gerszten RE, Wei R et al (2008) The M2 splice isoform of pyruvate kinase is important for cancer metabolism and tumour growth. Nature 452(7184):230

80. Mazurek S (2011) Pyruvate kinase type M2: a key regulator of the metabolic budget system in tumor cells. The international journal of biochemistry \& cell biology 43(7):969-980

81. Guo C, Linton A, Jalaie M, Kephart S, Ornelas M, Pairish M et al (2013) Discovery of 2-((1H-benzo [d] imidazol-1-yl) methyl)-4H-pyrido [1, 2-a] pyrimidin-4-ones as novel PKM2 activators. Bioorganic \& Medicinal Chemistry Letters 23(11):3358-3363

82. Maji B, Kumar K, Kaulage M, Muniyappa K, Bhattacharya S (2014) Design and Synthesis of new benzimidazole-carbazole conjugates for the stabilization 
of human telomeric DNA, telomerase inhibition, and their selective action on cancer cells. Journal of Medicinal Chemistry 57(16):6973-6988

83. Jain AK, Paul A, Maji B, Muniyappa K, Bhattacharya S (2012) Dimeric 1, 3phenylene-bis (piperazinyl benzimidazole) s: synthesis and structure-activity investigations on their binding with human telomeric G-quadruplex DNA and telomerase inhibition properties. Journal of Medicinal Chemistry 55(7): 2981-2993

84. Chen C-L, Chang D-M, Chen T-C, Lee C-C, Hsieh H-H, Huang F-C et al (2013) Structure-based design, synthesis and evaluation of novel anthra [1, 2-d] imidazole-6, 11-dione derivatives as telomerase inhibitors and potential for cancer polypharmacology. European Journal of Medicinal Chemistry 60:29-41

85. Shi L, Wu T-T, Wang Z, Xue J-Y, Xu Y-G (2014) Discovery of N-(2-phenyl-1Hbenzo [d] imidazol-5-yl) quinolin-4-amine derivatives as novel VEGFR-2 kinase inhibitors. European Journal of Medicinal Chemistry 84:698-707

86. Carmeliet P (2003) Angiogenesis in health and disease. Nature Medicine 9(6):653

87. Arcari JT, Beebe JS, Berliner MA, Bernardo V, Boehm M, Borzillo GV et al (2013) Discovery and synthesis of novel 4-aminopyrrolopyrimidine Tie-2 kinase inhibitors for the treatment of solid tumors. Bioorganic \& Medicinal Chemistry Letters 23(10):3059-3063

88. Patrick GL (2013) An introduction to medicinal chemistry: Oxford university press

89. Rowinsky EK (2003) Signal events: cell signal transduction and its inhibition in cancer. The Oncologist 8(Supplement 3):5-17.

90. Akhtar W, Khan MF, Verma G, Shaquiquzzaman M, Rizvi MA, Mehdi SH et al (2017) Therapeutic evolution of benzimidazole derivatives in the last quinquennial period. European Journal of Medicinal Chemistry 126:705-753

91. Liu W-Q, Megale V, Borriello L, Leforban B, Montes M, Goldwaser E et al (2014) Synthesis and structure-activity relationship of non-peptidic antagonists of neuropilin-1 receptor. Bioorganic \& Medicinal Chemistry Letters 24(17):4254-4259

92. Temirak A, Shaker YM, Ragab FA, Ali MM, Ali HI, El Diwani HI (2014) Part I. Synthesis, biological evaluation and docking studies of new 2furylbenzimidazoles as antiangiogenic agents. European Journal of Medicinal Chemistry 87:868-880

93. Abdullaziz MA, Abdel-Mohsen HT, El Kerdawy AM, Ragab FA, Ali MM, Abubakr SM et al (2017) Design, synthesis, molecular docking and cytotoxic evaluation of novel 2-furybenzimidazoles as VEGFR-2 inhibitors. European Journal of Medicinal Chemistry 136:315-329

94. Ashok A, Thanukrishnan K, Bhojya Naik HS, Maridu R (2017) Novel arylmodified benzoylamino- $\mathrm{N}$-(5, 6-dimethoxy-1H-benzoimidazol-2-yl)heteroamides as potent inhibitors of vascular endothelial growth factor receptors 1 and 2. Journal of Heterocyclic Chemistry 54(3):1949-1956

95. Liao JJ-L (2007) Molecular recognition of protein kinase binding pockets for design of potent and selective kinase inhibitors. Journal of Medicinal Chemistry 50(3):409-424

96. Zhang J, Yang PL, Gray NS (2009) Targeting cancer with small molecule kinase inhibitors. Nature reviews Cancer 9(1):28

97. Zuccotto F, Ardini E, Casale E, Angiolini M (2009) Through the "gatekeeper door": exploiting the active kinase conformation. Journal of Medicinal Chemistry 53(7):2681-2694

98. Determann R, Dreher J, Baumann K, Preu L, Jones PG, Totzke F et al (2012) 2-Anilino-4-(benzimidazol-2-yl) pyrimidines-A multikinase inhibitor scaffold with antiproliferative activity toward cancer cell lines. European Journal of Medicinal Chemistry 53:254-263

99. Akhtar MJ, Siddiqui AA, Khan AA, Ali Z, Dewangan RP, Pasha S et al (2017) Design, synthesis, docking and QSAR study of substituted benzimidazole linked oxadiazole as cytotoxic agents, EGFR and erbB2 receptor inhibitors. European Journal of Medicinal Chemistry 126:853-869

100. Lelais G, Epple R, Marsilje TH, Long YO, McNeill M, Chen B et al (2016) Discovery of $(\mathrm{R}, \mathrm{E})$-N-(7-Chloro-1-(1-[4-(dimethylamino) but-2-enoyl] azepan3-yl)-1 H-benzo [d] imidazol-2-yl)-2-methylisonicotinamide (EGF816), a novel, potent, and WT sparing covalent inhibitor of oncogenic (L858R, ex19del) and resistant (T790M) EGFR mutants for the treatment of EGFR mutant nonsmall-cell lung cancers. Journal of Medicinal Chemistry 59(14):6671-6689

101. Touat M, lleana E, Postel-Vinay S, André F, Soria J-C (2015) Targeting FGFR signaling in cancer. Clinical Cancer Research 21(12):2684-2694

102. Yan W, Wang X, Dai Y, Zhao B, Yang X, Fan J et al (2016) Discovery of 3-(5'Substituted)-benzimidazole-5-(1-(3, 5-dichloropyridin-4-yl) ethoxy)-1Hindazoles as potent fibroblast growth factor receptor inhibitors: design, synthesis, and biological evaluation. J Med Chem 59(14):6690-6708
103. Gryshchenko A, Tarnavskiy S, Levchenko K, Bdzhola V, Volynets G, Golub A et al (2016) Design, synthesis and biological evaluation of 5-amino-4-(1Hbenzoimidazol-2-yl)-phenyl-1, 2-dihydro-pyrrol-3-ones as inhibitors of protein kinase FGFR1. Bioorganic \& Medicinal Chemistry 24(9):2053-2059

104. Huang H, Bhat A, Woodnutt G, Lappe R (2010) Targeting the ANGPT-TIE2 pathway in malignancy. Nature Reviews Cancer 10(8):575-585

105. Hammond E, Handley P, Dredge K, Bytheway I (2013) Mechanisms of heparanase inhibition by the heparan sulfate mimetic PG545 and three structural analogues. FEBS open bio 3(1):346-351

106. Pan W, Miao H-Q, Xu Y-J, Navarro EC, Tonra JR, Corcoran E et al (2006) 1-[4(1H-Benzoimidazol-2-yl)-phenyl]-3-[4-(1H-benzoimidazol-2-yl)-phenyl]-urea derivatives as small molecule heparanase inhibitors. Bioorganic \& Medicinal Chemistry Letters 16(2):409-412

107. Dempke W, Rie C, Grothey A, Schmoll H-J (2001) Cyclooxygenase-2: a novel target for cancer chemotherapy? Journal of Cancer Research and Clinical Oncology 127(7):411-417

108. Gupta RA, DuBois RN (2001) Colorectal cancer prevention and treatment by inhibition of cyclooxygenase-2. Nature reviews Cancer 1(1):11

109. Abdelgawad MA, Bakr RB, Omar HA (2017) Design, synthesis and biological evaluation of some novel benzothiazole/benzoxazole and/or benzimidazole derivatives incorporating a pyrazole scaffold as antiproliferative agents. Bioorganic Chemistry.

110. Marugán C, Torres R, Lallena MJ (2016) Phenotypic screening approaches to develop aurora kinase inhibitors: drug discovery perspectives. Frontiers in Oncology 5:299

111. Pollard JR, Mortimore M (2009) Discovery and development of aurora kinase inhibitors as anticancer agents. Journal of Medicinal Chemistry 52(9):2629-2651

112. Zheng Y, Zheng M, Ling X, Liu Y, Xue Y, An L et al (2013) Design, synthesis, quantum chemical studies and biological activity evaluation of pyrazolebenzimidazole derivatives as potent Aurora A/B kinase inhibitors. Bioorganic \& Medicinal Chemistry Letters 23(12):3523-3530

113. Zhong M, Bui M, Shen W, Baskaran S, Allen DA, Elling RA et al (2009) 2Aminobenzimidazoles as potent Aurora kinase inhibitors. Bioorganic \& Medicinal Chemistry Letters 19(17):5158-5161

114. Howard S, Berdini V, Boulstridge JA, Carr MG, Cross DM, Curry J et al (2008) Fragment-based discovery of the pyrazol-4-yl urea (AT9283), a multitargeted kinase inhibitor with potent aurora kinase activity. Journal of Medicinal Chemistry 52(2):379-388

115. Sharma A, Luxami V, Paul K (2015) Purine-benzimidazole hybrids: synthesis, single crystal determination and in vitro evaluation of antitumor activities. European Journal of Medicinal Chemistry 93:414-422

116. Sherr CJ, Bartek J (2016) Cell cycle-targeted cancer therapies. Annual Review of Cancer Biology (0).

117. Bartek J, Falck J, Lukas J (2001) CHK2 kinase--a busy messenger. Nature reviews Molecular cell biology 2(12):877

118. Garcia-Limones C, Lara-Chica M, Jimenez-Jimenez C, Pérez M, Moreno P, Muñoz E et al (2016) CHK2 stability is regulated by the E3 ubiquitin ligase SIAH2. Oncogene 35(33):4289-4301

119. Song P, Peng P, Han M, Cao X, Ma X, Liu T et al (2014) Design, synthesis and biological evaluation of thienopyridinones as Chk1 inhibitors. Bioorganic \& Medicinal Chemistry 22(17):4882-4892

120. Ni Z-J, Barsanti P, Brammeier N, Diebes A, Poon DJ, Ng S et al (2006) 4(Aminoalkylamino)-3-benzimidazole-quinolinones as potent CHK-1 inhibitors. Bioorganic \& Medicinal Chemistry Letters 16(12):3121-3124

121. Neff DK, Lee-Dutra A, Blevitt JM, Axe FU, Hack MD, Buma JC et al (2007) 2Aryl benzimidazoles featuring alkyl-linked pendant alcohols and amines as inhibitors of checkpoint kinase Chk2. Bioorganic \& Medicinal Chemistry Letters 17(23):6467-6471

122. Galal SA, Abdelsamie AS, Shouman SA, Attia YM, Ali HI, Tabll A et al (2017) Part I: Design, synthesis and biological evaluation of novel pyrazolebenzimidazole conjugates as checkpoint kinase 2 (Chk2) inhibitors with studying their activities alone and in combination with genotoxic drugs. European Journal of Medicinal Chemistry 134:392-405

123. El-Naem SI, El-Nzhawy A, El-Diwani H, Abdel Hamid A (2003) Synthesis of 5substituted 2-methylbenzimidazoles with anticancer activity. Archiv der Pharmazie 336(1):7-17

124. Trembley J, Wang G, Unger G, Slaton J, Ahmed K (2009) Protein kinase CK2 in health and disease. Cellular and Molecular Life Sciences 66(11-12):1858-1867

125. Bian Y, Ye M, Wang C, Cheng K, Song C, Dong M, et al. (2013) Global screening of CK2 kinase substrates by an integrated phosphoproteomics workflow. Scientific Reports 3. 
126. Ruzzene M, Pinna LA (2010) Addiction to protein kinase CK2: a common denominator of diverse cancer cells? Biochimica et Biophysica Acta (BBA)Proteins and Proteomics 1804(3):499-504.

127. Schneider CC, Kartarius S, Montenarh M, Orzeszko A, Kazimierczuk Z (2012) Modified tetrahalogenated benzimidazoles with CK2 inhibitory activity are active against human prostate cancer cells LNCaP in vitro. Bioorganic \& Medicinal Chemistry 20(14):4390-4396

128. Pagano MA, Meggio F, Ruzzene $M$, Andrzejewska M, Kazimierczuk Z, Pinna LA (2004) 2-Dimethylamino-4, 5, 6, 7-tetrabromo-1H-benzimidazole: a novel powerful and selective inhibitor of protein kinase CK2. Biochemical and Biophysical Research Communications 321(4):1040-1044

129. Andrzejewska M, Pagano MA, Meggio F, Brunati AM, Kazimierczuk Z (2003) Polyhalogenobenzimidazoles: synthesis and their inhibitory activity against casein kinases. Bioorganic \& Medicinal Chemistry 11(18):3997-4002

130. Łukowska-Chojnacka E, Wińska P, Wielechowska M, Poprzeczko M, Bretner M (2016) Synthesis of novel polybrominated benzimidazole derivatives - potential CK2 inhibitors with anticancer and proapoptotic activity. Bioorganic \& Medicinal Chemistry 24(4):735-741

131. Malumbres M (2014) Cyclin-dependent kinases. Genome Biology 15(6):122

132. Lin R, Connolly PJ, Lu Y, Chiu G, Li S, Yu Y et al (2007) Synthesis and evaluation of pyrazolo [3,4-b] pyridine CDK1 inhibitors as anti-tumor agents. Bioorganic \& Medicinal Chemistry Letters 17(15):4297-4302

133. Gorgisen G, Gulacar I, Ozes O (2017) The role of insulin receptor substrate (IRS) proteins in oncogenic transformation. Cellular and Molecular Biology 63(1):1-5

134. Yu H, Rohan T (2000) Role of the insulin-like growth factor family in cancer development and progression. Journal of the National Cancer Institute 92(18):1472-1489

135. Baserga R (1995) The insulin-like growth factor I receptor: a key to tumor growth? Cancer Research 55(2):249-252

136. Wittman M, Carboni J, Attar R, Balasubramanian B, Balimane P, Brassil P et al (2005) Discovery of a (1 H-Benzoimidazol-2-yl)-1 H-pyridin-2-one (BMS536924) inhibitor of insulin-like growth factor I receptor kinase with in vivo antitumor activity. Journal of Medicinal Chemistry 48(18):5639-5643

137. Liu P, Cheng H, Roberts TM, Zhao JJ (2009) Targeting the phosphoinositide 3-kinase (PI3K) pathway in cancer. Nature reviews Drug discovery 8(8):627

138. Vanhaesebroeck B, Guillermet-Guibert J, Graupera M, Bilanges B (2010) The emerging mechanisms of isoform-specific PI3K signalling. Nature reviews Molecular cell biology 11(5):329

139. Van Dort ME, Hong $H$, Wang $H$, Nino CA, Lombardi RL, Blanks AE et al (2016) Discovery of bifunctional oncogenic target inhibitors against allosteric mitogen-activated protein kinase (MEK1) and phosphatidylinositol 3-kinase (PI3K). Journal of Medicinal Chemistry 59(6):2512-2522

140. Certal V, Halley F, Virone-Oddos A, Delorme C, Karlsson A, Rak A et al (2012) Discovery and optimization of new benzimidazole-and benzoxazolepyrimidone selective PI3K $\beta$ inhibitors for the treatment of phosphatase and TENsin homologue (PTEN)-deficient cancers. Journal of Medicinal Chemistry 55(10):4788-4805

141. Murarka S, Martín-Gago P, Schultz-Fademrecht C, Al Saabi A, Baumann M, Fansa EK et al (2017) Development of pyridazinone chemotypes targeting the PDE $\delta$ prenyl binding site. Chemistry-A European Journal 23(25):6083-6093

142. Zimmermann G, Schultz-Fademrecht C, Küchler P, Murarka S, Ismail S, Triola $\mathrm{G}$ et al (2014) Structure guided design and kinetic analysis of highly potent benzimidazole inhibitors targeting the PDE $\delta$ prenyl binding site. Journal of Medicinal Chemistry 57(12):5435-5448

143. Rewcastle GW, Gamage SA, Flanagan JU, Kendall JD, Denny WA, Baguley BC et al (2013) Synthesis and biological evaluation of novel phosphatidylinositol 3-kinase inhibitors: Solubilized 4-substituted benzimidazole analogs of 2-(difluoromethyl)-1-[4, 6-di (4-morpholinyl)-1, 3, 5-triazin-2-yl]-1H-benzimidazole (ZSTK474). European Journal of Medicinal Chemistry 64:137-147

144. Mortlock AA, Wilson DM, Kettle JG, Goldberg FW, Foote KM. Selective kinase inhibitors in cancer. Reference Module in Chemistry, Molecular Sciences and Chemical Engineering: Elsevier; 2017.

145. Marco-Contelles J, Soriano E (2011) Editorial [Hot topic: the medicinal chemistry of hybrid-based drugs targeting multiple sites of action (Guest Editors: Jose Marco-Contelles, \& Elena Soriano)]. Current Topics in Medicinal Chemistry 11(22):2714-2715

146. Shi L, Wu T-T, Wang Z, Xue J-Y, Xu Y-G (2014) Discovery of quinazolin-4amines bearing benzimidazole fragments as dual inhibitors of c-Met and VEGFR-2. Bioorganic \& Medicinal Chemistry 22(17):4735-4744
147. Renhowe PA, Pecchi S, Shafer CM, Machajewski TD, Jazan EM, Taylor C et al (2008) Design, structure-activity relationships and in vivo characterization of 4-amino-3-benzimidazol-2-ylhydroquinolin-2-ones: a novel class of receptor tyrosine kinase inhibitors. Journal of Medicinal Chemistry 52(2):278-292

148. Li Y, Tan C, Gao C, Zhang C, Luan X, Chen X et al (2011) Discovery of benzimidazole derivatives as novel multi-target EGFR, VEGFR-2 and PDGFR kinase inhibitors. Bioorganic \& Medicinal Chemistry 19(15):4529-4535

149. McBride CM, Renhowe PA, Heise C, Jansen JM, Lapointe G, Ma S et al (2006) Design and structure-activity relationship of 3-benzimidazol-2-yl-1Hindazoles as inhibitors of receptor tyrosine kinases. Bioorganic \& Medicinal Chemistry Letters 16(13):3595-3599

\section{Publisher's Note}

Springer Nature remains neutral with regard to jurisdictional claims in published maps and institutional affiliations.

\section{Submit your manuscript to a SpringerOpen ${ }^{\circ}$ journal and benefit from:}

- Convenient online submission

- Rigorous peer review

- Open access: articles freely available online

High visibility within the field

- Retaining the copyright to your article

Submit your next manuscript at $>$ springeropen.com 